$11-2021$

\title{
Implementing Geriatric Frailty Screening in Acute Care
}

Christine Longley

University of St. Augustine for Health Sciences, c.longley@usa.edu

DOI: https://doi.org/10.46409/sr.QISG9893

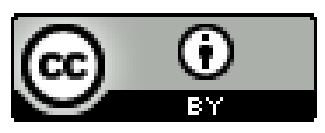

This work is licensed under a Creative Commons Attribution 4.0 License.

Follow this and additional works at: https://soar.usa.edu/scholprojects

Part of the Geriatric Nursing Commons

\section{Recommended Citation}

Longley, C. (2021). Implementing Geriatric Frailty Screening in Acute Care. [Doctoral project, University of St Augustine for Health Sciences]. SOAR @ USA: Student Scholarly Projects Collection. https://doi.org/ 10.46409/sr.QISG9893

This Scholarly Project is brought to you for free and open access by the Student Research at SOAR @ USA. It has been accepted for inclusion in Student Scholarly Projects by an authorized administrator of SOAR @ USA. For more information, please contact soar@usa.edu, erobinson@usa.edu. 


\section{Implementing Geriatric Frailty Screening in Acute Care}

Christine Michelle Longley, MSN, RN, NP-C, AGCNS-BC School of Nursing, University of St. Augustine for Health Sciences

This Manuscript Partially Fulfills the Requirements for the Doctor of Nursing Practice Program and is Approved by:

Sarah M. I. Cartwright, DNP, MSN-PH, BAM, RN-BC, CAPA, FASPAN

Kathleen Rea, DNP, APRN, ACNS-BC, PCCN, CNL

Approved: November 18, 2021 


\begin{abstract}
Practice Problem: Frailty is a syndrome of age-related physiologic decline characterized by an increased burden of symptoms and higher susceptibility to adverse health, including higher functional decline rates, pressure ulcers, falls, and delirium. In the general medicine unit of this project, geriatric patients were not screened for frailty.

PICOT: The PICOT question that guided this project was: In hospitalized patients 65-years-ofage and older $(\mathrm{P})$, how does implementing a geriatric frailty screening tool (I), compared to standard assessments (C), influence frailty identification and personalized plans of care (O) over eight weeks (T)?

Evidence: Literature supports screening for frailty in the hospitalized geriatric population.

Intervention: For eight weeks, a group of four RN clinicians piloted the CFS and collected data on patient appropriateness for screening, completion of screening, CFS scores, and influence of CFS scoring on personalized patient care plans.
\end{abstract}

Outcome: Statistical analysis results suggest that completing the CFS and adjusting the individualized plan of care were related to one another.

Conclusion: Applying best practices to identify frailty during hospitalization demonstrated a measurable influence on health promotion in acutely ill geriatric patients. 


\section{Implementing Geriatric Frailty Screening in Acute Care}

Normal aging is usually characterized by predictable, progressive physiologic changes associated with higher susceptibility to multiple diseases and disabilities (Taffet, 2019). Frailty is a phenomenon within the geriatric population that is distinctly separate from disease or disability (Fried et al., 2004). Frailty is a syndrome of age-related physiologic decline characterized by an increased burden of symptoms and higher susceptibility to adverse health. An international physician consensus group formally defined frailty as "a medical syndrome with multiple causes and contributors that is characterized by diminished strength, endurance, and reduced physiologic function that increases an individual's vulnerability for developing increased dependency and/or death" (Morley et al., 2013, p. 4). Several characteristics are associated with higher prevalence of geriatric frailty, including smoking, female gender, Hispanic or African American ethnicity, depression, lower education level, and intellectual disability (BandeenRoche et al., 2015; de Labra et al., 2018; Evenhuis et al., 2012; Lakey et al., 2012; Woods et al., 2005).

In the acute care setting, geriatric frailty is associated with higher functional decline rates, pressure ulcers, falls, and delirium (Hubbard et al., 2017). Given the higher vulnerability to adverse health outcomes and reduced tolerance to adapt to acute illness, trauma, or medicalsurgical interventions, frailty screening should be implemented in patients 65 years and older (Morley et al., 2013). Screening for geriatric frailty may indicate an opportunity to implement interprofessional consultation and facilitate favorable or supportive discharge status. This evidence-based practice $(\mathrm{EBP})$ project implemented frailty screening on patients aged 65 years old or older admitted to a general medicine unit during an eight-week period. 


\section{Significance of the Practice Problem}

Frailty is an increased vulnerability to adverse health outcomes across clinical settings due to a decline in physiologic reserve related to age-related changes (Xue, 2011). The state of frailty leads to a prolonged and incomplete recovery after any new injury, stress, or acute disease (Perna et al., 2017). In the United States, $14.9 \%$ of the total population is geriatric, characterized as 65 years and older (U.S. Census Bureau, 2020). The US geriatric population has experienced rapid growth since 2011 as individuals born between 1946-1964, the Baby Boomer generation, began reaching 65 years old (U. S. Census Bureau, 2020). Frailty in the US geriatric population ranges from 4-16\% in community-dwelling elders over 65 years old, with prevalence increasing to $24 \%$ in individuals $90-94$ years old and $39.5 \%$ in individuals $>95$ years old (Cawthon et al., 2007). Nearly $40 \%$ of hospitalized adults are $>65$ years old, and frailty rates are estimated as high as $27.4 \%$, and pre-frailty rates range from $34.6-50.9 \%$ in this population (Archibald et al., 2019).

\section{Significance of Frailty on Patient/Family}

Geriatric frailty significantly impacts patients and families in several aspects of function, quality of life, and harm. In hospitalized patients identified with geriatric frailty, $45 \%$ experience functional decline characterized as requiring subacute care or additional services after discharge or performing below baseline function in daily living activities (Greorevic et al., 2016). This functional decline can lead to loss of independence and often requires increased support/dependency on family for Activities of Daily Living (ADLs) and Instrumental Activities of Daily Living (IADLs). Using a quality of life (QOL) questionnaire, QOL domains of health and mobility are lower in geriatric individuals identified with frailty than non-frail or pre-frail counterparts (Henchoz et al., 2016). Additionally, up to $38.6 \%$ of individuals identified with 
geriatric frailty experience a fall event, with over $50 \%$ of frailty geriatric falls resulting in injury and $78 \%$ resulting in fear of falling again (Fhon et al., 2013). Higher rates of pressure ulcer incidence and use of restraints during hospitalization are also associated with geriatric frailty (Barry \& Nugent, 2015; Gunawardena \& Smithard, 2019). Additionally, frailty is associated with higher 2-year mortality following hospitalization (Keeble et al., 2019).

\section{Significance of Frailty on the Health System}

Geriatric frailty significantly impacts the healthcare system across the continuum. Frail hospitalized geriatric patients can incur a longer length of stay and higher readmission rates than non-frail or pre-frail elders depending on admission diagnoses (Ritt et al., 2016). In patients admitted with atrial fibrillation, length of stay was 3-5 days longer in frail geriatric patients compared to non-frail geriatric patients, and readmissions occurred in nearly $74 \%$ of frail geriatric general medicine patients compared to 62\% of non-frail cohorts (Hao et al., 2019; Nguyen et al., 2015). Geriatric frailty also leads to higher use of skilled nursing facility resources, nursing home placement, and aged care services (De Silva et al., 2017).

\section{Significance of Frailty on Society}

Geriatric frailty is associated with particular social determinants and results in higher dependency on family and increased healthcare services needs with increased healthcare costs. Evaluating acute medical costs of U.S. Medicare patients in 2013, the mean cost of care over nine months for frail patients was $\$ 25,320$, compared to $\$ 16,305$ for pre-frail geriatric patients and \$8,099 for non-frail geriatric patients (Simpson et al., 2018). These costs represent a staggering opportunity to identify geriatric frailty and modify care strategies to maximize patient access to health promotion services, implement interventions to avoid adverse healthcare outcomes, and streamline service costs (Cunha et al., 2019; Lee et al., 2020; Xue, 2011). 


\section{PICOT Question}

Compared to non-frail geriatric patients, frail geriatric patients are unique with higher risks for poor healthcare outcomes. These poor outcomes include increased incidence of adverse events during hospitalization, incurring longer lengths of stay, experiencing higher hospital readmission rates, and having an increased need for institutionalization after hospital discharge (Engelhardt et al., 2018; Walston et al., 2018). Given these adverse outcomes personal and organizational impact on hospitalized elders, this practice project sought to implement a geriatric frailty screening process. In hospitalized patients 65-years-of-age and older (P), how does implementing a geriatric frailty screening tool (I), compared to standard assessments (C), influence frailty identification and personalized plans of care $(\mathrm{O})$ over eight weeks $(\mathrm{T})$ ? This project focused on hospitalized patients 65 years and older in a general medicine unit in an academic medical center in the southern United States. On the general medicine unit, registered nurses and advanced practice providers assess all adult patients using standard head-to-toe assessments with additional separate screenings focused on falls, delirium, and hospital-acquired pressure injury risk. On this unit, geriatric patients are currently not explicitly screened for geriatric frailty. Patients 65 and older were screened using a geriatric frailty screening tool during the eight-week project implementation period. Data were collected on patient appropriateness for frailty screening, compliance of frailty screening, frailty scores, and the influence of frailty scoring on personalized patient care plans.

\section{Evidence-Based Practice Framework \& Change Theory}

The Johns Hopkins Nursing Evidence-Based Practice (JHNEBP) model was used to guide the implementation of this geriatric frailty screening project and evaluate the impact of frailty screening on individualized plans of care. The JHNEBP utilizes three steps: practice 
question, evidence, and translation (Dang \& Dearholt, 2017). Using the JHNEBP framework, the first step of this project focused on recruiting a group of clinicians to implement frailty screening on the general medicine unit, defining the problem, refining the evidence-based practice question for geriatric frailty screening, and identifying unit-based and organizational stakeholders. The second step entailed searching for evidence related to geriatric frailty screening and interventions, appraising, summarizing, synthesizing the level and quality of evidence, and developing a formal recommendation for practice change based on compelling evidence. The final step included determining the appropriateness of implementing geriatric frailty screening, creating and implementing an action plan, evaluating outcomes, reporting results, and disseminating findings based on results.

Lewin's change theory is the foundation for this project. Lewin's theory recognizes change as a dynamic balance of driving and restraining forces working in opposite directions within a group/system (Lewin, 1951; White et al., 2021; Zaccagnini \& White, 2014). Lewin's theory highlights three stages of change: unfreezing, moving, and refreezing. Unfreezing is characterized by identifying a need for change and preparing participants for the upcoming change; in this project, unfreezing identified the impact of geriatric frailty and collaborated with clinicians to conceptualize geriatric frailty screening in general medicine patients. The moving stage includes implementing the change while balancing motivating forces and minimizing barriers; for this project, moving included piloting a geriatric frailty screening tool and measuring appropriateness of patients, compliance of screening, frailty scores, and impact of frailty scoring. Finally, refreezing formalizes the change and disseminates results; in this project, refreezing formalized geriatric frailty screening on the general medicine unit. 


\section{Evidence Search Strategy}

A literature search reviewed publications between 2001-2021 from the Cumulative Index for Nursing and Allied Health Literature (CINAHL), ProQuest, PubMed, and Cochrane Library. This search spanned 20 years because 2001 was the original publication year of the Fried frailty phenotype. Keywords used in this literature database search included "geriatric frailty (screening OR assessment OR questionnaire) AND acute care." Additional alternate keywords included "aged" and "hospital." Additional filters based on specific inclusion and exclusion criteria focused search results on relevant content. Inclusion criteria include articles published between 2001-2021 in English in peer-reviewed journals and reviewed frailty screening in patients aged 65 and older in acute care or hospital settings. Exclusion criteria for studies eliminated those not focused on geriatric frailty screening or not performed in the acute/hospital setting.

\section{Evidence Search Results}

The initial search results included 1757 total articles from CINAHL (141), ProQuest (1308), PubMed (281), and Cochrane (2). Titles and abstracts were reviewed, with inclusion and exclusion criteria applied. The initial review excluded 1711 articles for not meeting inclusion criteria or including exclusion criteria. Articles were excluded due to not including a study or studying the impact of the Comprehensive Geriatric Assessment, which is not a screening tool. Forty-six articles were extracted for full-text review, and 26 were excluded after full-text screening due to limited evidence supporting reliability, validity, or application with measurable outcomes, as shown in Figure 1. Twenty articles are included in the Evidence Summary Table (see Appendix A). Of the twenty articles, six individual frailty screening tools were studied, and two tools had several studies validating use: eleven studies focused on the Clinical Frailty Scale (CFS), and three focused on the FRAIL Questionnaire. The 14 focused on the CFS and FRAIL 
questionnaire and reflected Level III evidence with 8 Quality Grade A, 5 Quality Grade B, and 1

Quality Grade C. The four other screening tools included studies with Level III (4 studies), Level IV (1 study), and Level V (1 study). Currently, there are no randomized controlled trials testing a geriatric frailty screening against a control.

\section{Themes with Practice Recommendations}

Frailty describes the increased vulnerability of select individuals to adverse outcomes compared to people within the same chronologic age. Since the foundational conceptual model of geriatric frailty in 2001, research on geriatric frailty has produced an expanding body of literature that focuses on the impact of frailty on patient outcomes (Maxwell et al., 2019). As the global life expectancy lengthens, the number of older patients presenting with frailty continues to rise (Zhao et al., 2020). Because not all older adults are frail, recent literature highlights the importance of identifying geriatric frailty to avoid or anticipate and prepare for adverse outcomes (Theou et al., 2018).

\section{Population}

In a review of geriatric frailty screening literature, 20 articles focused on screening for frailty in hospitalized geriatric patients during hospitalization. Nearly $40 \%$ of hospitalized adults are $>65$ years old, and frailty rates are estimated as high as $4.9 \%-27.4 \%$, and pre-frailty rates range from 34.6-50.9\% in the geriatric population (Archibald et al., 2019). Fifteen studies focused on geriatric patients presenting with various conditions and diagnoses and admitted to acute or intensive care units. A unique theme in five studies focused on frailty screening in geriatric patients presenting with trauma or requiring emergency surgical interventions. These studies on frailty screening reflected research across several continents: North America with six studies from the United States and Canada; Europe with six studies from the United Kingdom 
and Spain; South America with three studies from Brazil; Asia with three studies from Singapore and Bejing; and two studies from New Zealand and Australia (Aliberti et al., 2018, 2019; Aprahamian et al., 2018; Brummel et al., 2017; Cheung et al., 2017; Chong et al., 2017, 2019; Curtis et al., 2018; Ellis et al., 2020; Engelhardt et al., 2018; Flaatten et al., 2017; Hilmer et al., 2009; Hii et al., 2015; Ibrahim et al., 2019; Joseph et al., 2014; Liu et al., 2020; Maxwell et al., 2018; Moreno-Arino et al., 2020; Pugh et al., 2019; Torsney \& Romero-Ortuno, 2018).

\section{Ease of Use}

The most effective and accurate method to identify geriatric frailty is conducting a Comprehensive Geriatric Assessment (CGA). However, the time and resource requirement for a CGA is often not possible in the acute care setting, and a more rapid screening tool is desirable. The 20 studies in this review included six different frailty screening tools: 11 used the Clinical Frailty Scale (CFS); three used the FRAIL Questionnaire; and the Reported Edmonton Frail Scale (REFS), Emergency General Surgery Specific Frailty Index, Trauma Specific Frailty Index, and Targeted Geriatric Assessment (TaGA) each had two studies. As shown in Table 1, the six different frailty tools used in 20 studies evaluated different functional, cognitive, and health status components. All six frailty tools evaluated gait or ambulation. Five focused on Activities of Daily Living (ADLs), Instrumental Activities of Daily Living (IADLs), and nutrition. Four tools included evaluating mood, and three tools evaluated symptoms/health perception, cognitive status, comorbidities, and the ability to climb stairs (resistance). Fatigue, polypharmacy, sexual activity, and falls were included in two tools. Furthermore, hospitalizations/ED visits in the previous 12 months and urinary incontinence were each evaluated in one tool (Aliberti et al., 2018, 2019; Aprahamian et al., 2018; Brummel et al., 2017; Cheung et al., 2017; Chong et al., 2017, 2019; Curtis et al., 2018; Ellis et al., 2020; Engelhardt et 
al., 2018; Flaatten et al., 2017; Hilmer et al., 2009; Hii et al., 2015; Ibrahim et al., 2019; Joseph et al., 2014; Liu et al., 2020; Maxwell et al., 2018; Moreno-Arino et al., 2020; Pugh et al., 2019; Torsney \& Romero-Ortuno, 2018).

\section{Prediction of Outcomes}

Nearly all tools in these 20 studies included 1-2 studies on user validity and reliability. Additionally, several tools were tested to determine the impact of frailty screening on patient outcomes prediction. The patient outcomes most often evaluated focused on predicting hospital mortality, extended length of stay, discharge dependence, need for institutionalization at discharge, 30-day survival, and 12-month survival. The CFS had two studies evaluating reliability/validity, and nine studies focused on patient outcomes (Brummel et al., 2017; Cheung et al., 2017; Chong et al., 2017, 2019; Curtis et al., 2018; Ellis et al., 2020; Flaatten et al., 2017; Liu et al., 2020; Moreno-Arino et al., 2020; Pugh et al., 2019; Torsney \& Romero-Ortuno, 2018). Literature supports screening for frailty in the hospitalized geriatric population. Based on the level of evidence, quality grades of evidence, the number of supportive articles, and tool content inclusion, the CFS had the most support for implementation (see Appendix B) (Brummel et al., 2017; Cheung et al., 2017; Chong et al., 2017, 2019; Curtis et al., 2018; Ellis et al., 2020; Flaatten et al., 2017; Liu et al., 2020; Moreno-Arino et al., 2020; Pugh et al., 2019; Torsney \& Romero-Ortuno, 2018). The practice recommendation for this EBP project was to implement the CFS in hospitalized general medicine patients 65 years of age and older to determine how the CFS influenced geriatric frailty identification and personalized plans of care during eight weeks. Data collection, evaluation, and analysis focused on patient appropriateness for frailty screening, compliance of frailty screening, CFS frailty scores, and influence of CFS scoring on personalized patient care plans. 


\section{Setting, Stakeholders, and Systems Change}

This project occurred at a not-for-profit level 1 trauma academic medical center in the southern United States. The organization's mission is focused on providing superlative quality, innovation, and excellence in patient care, health professional training, and creating health knowledge promoting diversity, equity, and inclusiveness (University of Virginia Health, 2020). This organization's main hospital has 612 beds with three designated acute care general medicine units. One of the general medicine units served as the geriatric frailty screening implementation setting. This unit has 27 beds, and over $50 \%$ of patients are older than 65 , with nearly $25 \%$ older than 80. The most common admitting diagnosis on this unit is sepsis. The unit's nurse-sensitive indicators reflect consistent outperformance of the National Database for Nursing Quality Indicators benchmarks in central line-associated bloodstream infections rate, catheter-associated urinary tract infection rate, and hospital-acquired pressure injuries. However, this unit demonstrates higher inpatient falls with injury than national peers and has a higher use of restraints than many other acute care units in the organization. Additionally, readmission data reveals this unit has the third-highest readmission rate across the organization.

Hospitalized frail elders have a higher risk of adverse events during hospitalization and increased dependence at discharge in frail elders. In this organization, general medicine physician leadership attempted to pilot an unvalidated frailty screening question 18-24 months before this EBP project. However, this previous screening was not considered valuable because it was inconsistently completed by inexperienced clinicians and did not activate any interprofessional interventions.

The directing physician for general medicine, geriatrics, and palliative care supported piloting a validated geriatric frailty screening tool. This organization's commitment to safety 
outcomes, revenue, and national recognition aligned with literature promoting geriatric frailty screening and improved care provision. Geriatric frailty screening implementation impacted micro-level change with individual patient screening and intervention implementation on an individual unit. Frailty screening and an interprofessional geriatric frailty program impact the meso-level of system change beyond a single unit. Based on current literature, factors contributing most consistently to geriatric frailty include dependence with ADLs and IADLs, impaired gait, and poor nutrition (Brummel et al., 2017; Cheung et al., 2017; Chong et al., 2017, 2019; Curtis et al., 2018; Ellis et al., 2020; Flaatten et al., 2017; Liu et al., 2020; Moreno-Arino et al., 2020; Pugh et al., 2019; Torsney \& Romero-Ortuno, 2018). Interprofessional collaboration is essential to maximizing the care of frail geriatric patients. This project's interprofessional stakeholders included a group of clinicians recruited to screen for geriatric frailty and unit nursing clinicians, physicians, physical therapy (PT), occupational therapy (OT), social work, palliative care, and registered dieticians. Sustainability planning included the spread of geriatric frailty screening to other units and departments with completion by other clinicians. The longterm objectives included leveraging the electronic medical record (EMR) to trigger a geriatric frailty order set with interprofessional best practices based on CFS scores.

An analysis of this project's strengths, weaknesses, opportunities, and threats (SWOT) revealed project advantages included a current interest in frailty identification, extremely competent staff, a geriatric expert APRN project manager, and alignment with organizational priorities for improved patient outcomes. However, project vulnerability was also due to limited interprofessional staffing availability, competing priorities, and limited familiarity with the Clinical Frailty Scale (see Appendix C). 


\section{Implementation}

The objectives of this EBP project were

- Implement the CFS to all patients >65 years old admitted during the eight-week pilot

- Evaluate patient appropriateness and compliance of frailty screening completion

- Evaluate CFS frailty scores and influence of CFS scoring on personalized patient care plans.

Lewin's change theory and the Johns Hopkins Nursing Evidence-Based Practice (JHNEBP) model guided the development of this geriatric frailty screening project. As shown in Table 2 for this EBP project, Lewin's change theory's three stages of change align with the JHNEBP three-step process and 19 JHNEBP activities. Unfreezing within Lewin's change theory can be associated with the JHNEBP Practice Question step and activities associated with identifying a need for change through an interprofessional team and defining a problem, identifying possible change strategies based on review and synthesis of the literature, and identifying support for change by interfacing with key stakeholders. In this EBP project, these elements occurred with the project manager consulting clinical leaders for changes needed in geriatric practices and recognizing a need for geriatric frailty identification. The move phase of Lewin's change theory aligns with JHNEBP activities to develop an action plan, provide education to make a change, implement a change, and evaluate the results. In this EBP project, the project manager developed an action plan to implement the CFS on geriatric patients admitted to an acute care general medicine and identify the influence of frailty scores on personalized plans of care (see Appendix D). The final refreeze stage corresponds with the JHNEBP Translation Step associated with dissemination. In this EBP project, the project 
manager reported geriatric frailty screening results to interprofessional stakeholders for practice implications and dissemination to organization leadership.

The Doctor of Nursing Practice (DNP) student served as the project manager in this EBP project, facilitating organization, collaboration, and prioritization. Using standard project management tools, the DNP student is equipped to complete a needs assessment, develop topic expertise, identify stakeholders, scope an EBP project, and determine the project flow (Zaccagnini \& White, 2014). Proficiency in project flow and estimating completion times allowed the EBP project manager to determine the sequence of project tasks, parallel work and ultimately plan the implementation and dissemination completion times. In this EBP project, the project manager was a geriatric nurse practitioner and adult geriatric clinical nurse specialist with over ten years of project management experience and an established interprofessional collegial network.

Two weeks before project implementation, the APRN project manager completed CFS education to a group of clinicians. Training on CFS completion utilized resources developed from the CFS creators from the Department of Medicine at Dalhousie University, associated with the Geriatric Medicine Research (GMR) department of Nova Scotia Health (see Appendix B \& E). Permission was obtained for the use of the CFS (see Appendix F). The implementation portion of this EBP project included eight weeks of a group of clinicians using the CFS to score hospitalized geriatric patients' frailty levels (see Appendix G). Clinicians recorded patient appropriateness for frailty screening, compliance of frailty screening, CFS frailty scores, and the influence of CFS scoring on personalized patient care plans on a paper tool (see Appendix H). After eight weeks of CFS piloting, the project manager evaluated and analyzed findings for four weeks and discussed results with the interprofessional stakeholder team and organizational 
leadership. This EBP project budget included 10 hours for clinicians screening for geriatric frailty and materials to inform the project team and unit staff, as shown in Table 3 . Throughout this DNP project, interprofessional leadership was kept apprised of project status.

\section{Results}

\section{Data Collection}

For eight weeks, a group of four RN clinicians collected data on patient appropriateness for frailty screening, completion of frailty screening, CFS frailty scores, and influence of CFS scoring on personalized patient care plans. The group of clinicians completed data collection with 40 participants through verbal interactions with the participants and/or family/care provider using a paper collection tool (see Appendix H). The APRN project manager collected the paper forms and transcribed data into an electronic spreadsheet to store and analyze data. The risk of privacy of participants was impacted by semi-private patient rooming. Participant exclusions were those admitted $>24$ hours before data collection for the day and those who could not describe functional level before admission and information was not available from other sources. However, the CFS did not include disclosure of sensitive information and focused on ADL/IADL independence and functional and physical status before admission (Hicks, 2019a, 2019b). (See Appendix B).

\section{Data Evaluation}

Data evaluation utilized primary data in this EBP project from the patient or family/caregivers. Descriptive data analysis evaluated patient appropriateness for frailty screening, compliance of frailty screening, CFS frailty scores, and influence of CFS scoring on personalized patient care plans after the pilot for summative evaluation. There are no 
benchmarks for geriatric frailty screening or benchmarks for other data elements in this EBP project. Project measures, level of data, and statistical analysis are shown in Table 4.

Missing data was limited to the CFS scores of four participants who were not screened using the CFS; the CFS completion data and individualized plan of care data were included in evaluation and analysis to determine comparison/associations. Completed data collection sheets were kept in a locked office, and data collection software storage was stored on a passwordprotected computer. Confidentiality was maintained because data collection did not include participant identifying information. The data in this EBP project was not protected health information and did not violate the Health Insurance Portability and Accountability Act Privacy Rule (see Appendix H) (United States Department of Health \& Human Services, 2012).

\section{Data Analysis}

This pilot included 40 participants with an average age of 75.33 years $(\mathrm{SD}=7.31)$ as shown in Table 5. All participants were appropriate for CFS screening, 90\% were screened $(n=36)$, and $90 \%$ experienced an adjustment to the individualized plan of care $(n=35)$. Of the 36 screened with the CFS, the average CFS score was $5.56(\mathrm{SD}=1.78)$.

Most data elements in this pilot project were nominal and statistical analysis focused on determining associations through the chi-square test and Fisher exact test as shown in Table $6 \&$ 7 (Kim \& Mallory, 2017). A chi-square test of independence was conducted to examine whether CFS completion (completed, not completed) and plan of care (adjusted, not adjusted) were independent. The results of the chi-square test were significant based on an alpha value of 0.05 , $\chi 2(1)=20.86, p<.001$, suggesting that completed and plan of care are related to one another. Due to the small sample size of this project, a Fisher exact test was used to supplement the chisquare results. The results of the Fisher exact test were significant based on an alpha value of 
$0.05, \mathrm{p}=.002$, suggesting that completion of the CFS and adjustment to the individualized plan of care are related to one another $(\mathrm{OR}=68.12)$.

Clinically meaningful change in this project focused on completing the frailty screening and the influence of CFS scoring on personalized patient care plans. The CFS screening identified various levels of frailty between 3 (managing well) and 9 (terminally ill). No participants were scored 1 (very fit) or 2 (well). In the hospital setting, the CFS guided clinicians and patients to identify pre-morbid frailty status. This view of pre-morbid illness and functional independence facilitated patient and provider goal setting, planning, and interprofessional consultation. In this project, clinicians performing screening reported the CFS improved awareness of pre-hospital ADL/IADL independence and frequently focused interventions for pro-active mobilization, toileting, cognitive stimulation, and PT or OT consultation. In this eightweek project of hospitalized general medicine patients 65-years-of-age and older, a valid geriatric frailty screening tool influenced frailty identification and personalized plans of care.

\section{Project Approval}

Permission was obtained for the use of the CFS. (See Appendix F). The University of St. Augustine for Health Sciences Evidence-based Project Review Committee approved this EBP project. The IRB of the organization where CFS piloting occurred designated this project as QI and not research.

\section{Impact}

Hospitalized frail older patients frequently have a reduced tolerance to medical interventions and a higher risk for adverse events. This pilot project sought to determine the impact of geriatric frailty screening and revealed that frailty identification influenced patients' personalized care plans. Applying best practices to identify frailty during hospitalization 
demonstrated a measurable influence on risk reduction and health promotion in acutely ill geriatric patients. The CFS effect was shown in a patient who scored Mildly Frail (5) and was being discharged after a lengthy ED stay and overnight admission. After screening, the CFS revealed that this patient needed more assistance at home than realized by the primary team. Without adequate resources, the patient would likely require readmission very quickly. The CFS led to consultation with PT, OT, and orders for home health services, including home safety evaluation, OT, PT, and Social Work. The CFS objectively identified this patient's frailty, and the frailty score prompted the primary team to adjust the patient's plan of care. This is an example of the effect seen throughout the population of interest within this EBP project. The use of the CSF consistently improved the identification of frailty concerns that may have been overlooked before implementation and increased interprofessional collaborative interventions based on patient needs.

Limitations of this project included small sample size and the use of a paper screening tool. Using a paper screening tool was challenging for clinicians because all patient condition documentation is electronic, and the paper CFS tool was not part of routine workflows. Additionally, one clinician was confused by scoring as a single number (versus adding scores) because the paper format did not clarify only a single score was needed. This format also required the collection of paper forms and manual entry into software to evaluate data and trends. The CFS does not include nutrition status within the screening content despite poor nutrition being a primary contributing factor in geriatric frailty. There is a gap in the current literature on what interventions should be automatically implemented based on frailty screening scores. Therefore, frailty screening is a clinical prompt to assess additional patient details related to nutrition, ADLs, and IADLs. 
Future implications for the Clinical Frailty Scale include recommendations to add it to the organization's electronic medical record admission database. An electronic screening tool aligns with the current RN admission practices workflow. Interprofessional access to the CFS through the EMR will facilitate sharing frailty information and potentially prompt interventions based on unique patient needs.

\section{Dissemination}

This evidence-based practice project and outcomes were shared within the facility in October 2021 and will be shared across the professional community in 2022 . The project manager shared results with the group of screening clinicians and the unit manager, unit medical director; associate chief medical officer; general medicine nursing director; therapies director; registered dieticians director; palliative care director; nursing practice director; clinical nurse specialist lead; and APRN project manager preceptor. The project manager met with physician and nursing leadership to discuss practice implications. Expanding the CFS to other clinical groups is planned once unit/service line staffing stability and acuity allows. Executive leadership review of practice proposals in situation, background, assessment, and recommendation (SBAR) format for widespread practice implementation will occur with the expansion of the CFS.

For external dissemination, this pilot's project manager submitted an oral poster presentation related to project background and results in November 2021. Additionally, the project's manuscript was submitted to the Scholarship and Open Access Repository (SOAR@USA). The project manager has prepared abstract submissions for consideration of presentation to the Gerontological Advanced Practice Nurse Association and the Nurses Improving the Care of Healthsystem Elders national conferences 2022 submission window for dissemination of results. Before abstract, presentation, and manuscript submission, peer review 
will occur with the project manager's preceptor and another Clinical Nurse Specialist Doctor of Nursing Practice peer.

\section{Conclusion}

This EBP project sought to determine whether the Clinical Frailty Scale implementation influenced personalized patient care plans for different frailty scores. Geriatric frailty is associated with a negative impact on function, quality of life, and harm. Aligned with best practices, geriatric frailty screening influenced patient care through objective frailty scoring and influencing interprofessional interventions. Screening for geriatric frailty presents an opportunity to identify vulnerable and frail individuals to maximize access to health and comfort expertise to improve healthcare outcomes and streamline service costs. 


\section{References}

Aliberti, M., Apolinario, D., Suemoto, C. K., Melo, J. A., Fortes-Filho, S. Q., Saraiva, M. D., Trindade, C. B., Covinsky, K. E., \& Jacob-Filho, W. (2018). Targeted geriatric assessment for fast-paced healthcare settings: Development, validity, and reliability. Journal of the American Geriatrics Society, 66(4), 748-754. https://doi.org/10.1111/jgs.15303

Aliberti, M., Covinsky, K. E., Apolinario, D., Lee, S. J., Fortes-Filho, S. Q., Melo, J. A., Viana, S., Suemoto, C. K., \& Jacob-Filho, W. (2019). A 10-min targeted geriatric assessment predicts mortality in fast-paced acute care settings: A prospective cohort study. The Journal of Nutrition, Health \& Aging, 23(3), 286-290. https://doi.org/10.1007/s12603$\underline{018-1152-Z}$

Aprahamian, I., Suemoto, C. K., Aliberti, M. J. R., Filho, S. Q. F., Melo, J. A., Lin, S. M., \& Filho, W. J. (2018). Frailty and cognitive status evaluation can better predict mortality in older adults? Archives of Gerontology and Geriatrics, 77, 51-56. https://doi.org/10.1016/j.archger.2018.04.005

Archibald, M., Lawless, M., Ambagtsheer, R. C., \& Kitson, A. (2020). Older adults' understandings and perspectives on frailty in community and residential aged care: An interpretive description. BMJ open, 10(3), e035339. https://doi.org/10.1136/bmjopen$\underline{2019-035339}$

Bandeen-Roche, K., Seplaki, C. L., Huang, J., Buta, B., Kalyani, R. R., Varadhan, R., Xue, Q. L., Walston, J. D., \& Kasper, J. D. (2015). Frailty in older adults: A nationally representative profile in the United States. The Journals of Gerontology, 70(11), $1427-$ 1434. https://doi.org/10.1093/gerona/glv133 
Barry, M., \& Nugent, L. E. (2015). Pressure ulcer prevention in frail older people. Nursing Standard, 30(16), 50-60. https://doi.org/10.7748/ns.30.16.50.s46

Brummel, N. E., Bell, S. P., Girard, T. D., Pandharipande, P. P., Jackson, J. C., Morandi, A., Thompson, J. L., Chandrasekhar, R., Bernard, G. R., Dittus, R. S., Gill, T. M., \& Ely, E. W. (2017). Frailty and subsequent disability and mortality among patients with critical illness. American Journal of Respiratory and Critical Care Medicine, 196(1), 64-72. https://doi.org/10.1164/rccm.201605-09390C

Cawthon, P. M., Marshall, L. M., Michael, Y., Dam, T. T., Ensrud, K. E., Barrett-Connor, E., Orwoll, E. S., \& Osteoporotic Fractures in Men Research Group (2007). Frailty in older men: prevalence, progression, and relationship with mortality. Journal of the American Geriatrics Society, 55(8), 1216-1223. https://doi.org/10.1111/j.1532-5415.2007.01259.x

Cheung, A., Haas, B., Ringer, T. J., McFarlan, A., \& Wong, C. L. (2017). Canadian Study of Health and Aging Clinical Frailty Scale: Does it predict adverse outcomes among geriatric trauma patients? Journal of the American College of Surgeons, 225(5):658665.e3. http://dx.doi.org/10.1016/j.jamcollsurg.2017.08.008

Chong, E., Chia, J. Q., Law, F., Chew, J., Chan, M., \& Lim, W. S. (2019). Validating a standardized approach in administration of the Clinical Frailty Scale in hospitalized older adults. Annals of Academic Medicine Singapore, 48, 115-124.

Chong, E., Ho, E., Baldevearona-Llego, J., Chan, M., Wu, L., Tay, L., Ding, Y. Y., \& Lim, W. S. (2017). Frailty in hospitalized older adults: Comparing different frailty measures in predicting short- and long-term patient outcomes. Journal of the American Medical Directors Association, 19, 450-457. https://doi.org/10.1016/j.jamda.2017.10.006 
Cunha, A. I. L., Veronese, N., Borges, S. M., \& Rocco, N. A. (2019). Frailty as a predictor of adverse outcomes in hospitalized older adults: A systematic review and meta-analysis. Aging Research Reviews, 56, 100960. https://doi.org/10.1016/j.arr.2019.100960

Curtis, E., Romanowski, K., Sen. S., Hill, A., \& Cocanour, C. (2018). Frailty score on admission predicts mortality and discharge disposition in elderly trauma patients over the age of 65 y. Journal of Surgical Research, 230, 13-19. https://doi/org/10.1016/j.jss.2018.04.017

Dalhousie University. (2021). Clinical frailty scale. https://www.dal.ca/sites/gmr/our-tools/clinical-frailty-scale.html

Dang, D., \& Dearholt, S. (2017). Johns Hopkins nursing evidence-based practice: model and guidelines. 3rd ed. Indianapolis, IN: Sigma Theta Tau International

de Labra, C., Maseda, A., Lorenzo-López, L., López - López, R., Bujan, A., RodriguezVillamil, J. L., Millan-Caenti, J. C. (2018). Social factors and quality of life aspects on frailty syndrome in community-dwelling older adults: the VERISAÚDE study. BMC Geriatrics, 18(66), 1-9. https://doi.org/10.1186/s12877-018-0757-8

De Silva, T., Ahip, S., Theou, O. I., Tufanaru, C., Visvanathan, R., \& Umapathysivam, K. (2017). Frailty in nursing home residents: A scoping review protocol. JBI Database of Systematic Reviews and Implementation Reports, 15(8), 2040-2046. https://doi.org/10.11124/JBISRIR-2016-003115

Ellis, H. L., Wan, B., Yeung, M., Rather, A., Mannan, I., Bond, C., Harvey, C., Raja, N., DuteyMagni, P., Rockwood, K., Davis, D., \& Searle, S. D. (2020). Complementing chronic frailty assessment at hospital admission with an electronic frailty index (FI-Laboratory) comprising routine blood test results. Canadian Medical Association Journal, 192, E3-8. https://doi.10.1503/cmaj.190952 
Engelhardt, K. E., Reuter, Q., Liu, J., Bean, J. F., Barnum, J., Shapiro, M. B., Ambre, A., Dunbar, A., Markzon, M., Reddy, T. N., Schilling, C., \& Posluszny, J. A., Jr. (2018). Frailty screening and a frailty pathway decrease length of stay, loss of independence, and 30-day readmission rates in frail geriatric trauma and emergency general surgery patients. The Journal of Trauma and Acute Care Surgery, 85(1), 167-173. https://doi.org/10.1097/TA.0000000000001931

Fhon, J. R., Rosset, I., Freitas, C. P., Silva, A. O., Santos, J. L., \& Rodrigues, R. A. (2013). Prevalence of falls among frail elderly adults. Revista de Saude Publica, 47(2), 266-273. https://doi.org/10.1590/S0034-8910.2013047003468

Flaatten, H., De Lange, D. W., Morandi, A., Andersen, F. H., Artigas, A., Bertolini, G., Boumendil, A., Cecconi, M., Christensen, S., Faraldi, L., Fjølner, J., Jung, C., Marsh, B., Moreno, R., Oeyen, S., Ohman, C. A., Pinto, B. B., Soliman, I. W., Szczeklik, W., ... Guidet, B. (2017). The impact of frailty on ICU and 30-day mortality and the level of care in very elderly patients ( $\geq 80$ years). Intensive Care Medicine, 43, 1820-1828. https://doi.org/10.1007/s00134-017-4940-8

Fried, L. P., Ferrucci, L., Darer, J., Williamson, J. D., \& Anderson, G. (2004). Untangling the concepts of disability, frailty, and comorbidity: Implications for improved targeting and care. Journal of Gerontology: MEDICAL SCIENCES, 59(3), 255-263.

Gerontological Advanced Practice Nurses Association. (2021). About GAPNA. https://www.gapna.org/about

Gunawardena, R., \& Smithard, D. G. (2019). The attitudes towards the use of restraint and restrictive intervention amongst healthcare staff on acute medical and frailty wards - A brief literature review. Geriatrics, 4(3), 1-10. https://doi.org/10.3390/geriatrics4030050 
Hao, Q., Zhou, L., Dong, B., Yang, M., Dong, B., \& Weil, Y. (2019). The role of frailty in predicting mortality and readmission in older adults in acute care wards: A prospective study. Scientific reports, 9(1), 1-8. https://doi.org/10.1038/s41598-018-38072-7

Henchoz, Y., Bula, C., Guessous, I., \& Santos-Eggimann, B. (2016). Association between physical frailty and quality of life in a representative sample of community-dwelling Swiss older people. The Journal of Nutrition, Health, \& Aging, 21(5), 585-592. https://doi.org/10.1007/s12603-016-0772-4

Hicks, L. (2019a). Privacy and confidentiality. CITI Program https://www.citiprogram.org

Hicks, L. (2019b). Informed consent. CITI Program https://www.citiprogram.org

Hii, T. B., Lainchbury, J. G., \& Bridgman, P. G. (2015). Frailty in acute cardiology: Comparison of a quick clinical assessment against a validated frailty assessment tool. Heart, Lung \& Circulation, 24(6), 551-556. https://doi.org/10.1016/j.hlc.2014.11.024

Hilmer, S. N., Perera, V., Mitchell, S., Murnion, B. P., Dent, J., Bajorek, B., Matthews, S., \& Rolfson, D. B. (2009). The assessment of frailty in older people in acute care. Australasian Journal on Ageing, 28(4), 182-188. https://doi.org/10.1111/j.1741$\underline{6612.2009 .00367 . x}$

Ibrahim, K., Howson, F. F. A., Culliford, D. J., Sayer, A. A., \& Roberts, H. C. (2019). The feasibility of assessing frailty and sarcopenia in hospitalized older people: A comparison of commonly used tools. BMC Geriatrics, 19(42), 1-7. https://doi.org/10.1186/s12877$\underline{019-1053-y}$

Joseph, B., Pandit, V., Zangbar, B., Kulvatunyou, N., Tang, A., O’Keefe, T., Green, D. J., Vercruysse, G., Fain, M. J., Friese, R. S., Rhee, P. (2014). Validating trauma-specific frailty index for geriatric trauma patients: A prospective analysis. Journal of the 
American College of Surgeons, 219(1), 10-17e.

https://doi.org/10.1016/j.jamcollsurg.2014.03.020

Keeble, E., Roberts, H. C., Williams, C. D., Van Oppen, J., \& Conroy, S. P. (2019). Outcomes of hospital admissions among frail older people: A 2-year cohort study. The British Journal of general practice: the Journal of the Royal College of General Practitioners, 69(685), e555-e560. https://doi.org/10.3399/bjgp19X704621

Kim, M. \& Mallory, C. (2017). Statistics for evidence-based practice in nursing (2nd ed.). Jones \& Barlett Learning.

Lakey, S. L., LaCroix, A. Z., Gray, S. L., Borson, S., Williams, C. D., Calhoun, D., Goveas, J. S., Smoller, J. W., Ockene, J. K., Masaki, K. H., Coday, M., Rosal, M. C., \& Woods, N. F. (2012). Antidepressant use, depressive symptoms, and incident frailty in women aged 65 and older from the Women's Health Initiative Observational Study. Journal of the American Geriatrics Society, 60(5), 854-861. https://doi.org/10.1111/j.1532-5415.2012.03940.x

Lee, H., Lee, E., \& Jang, I. Y. (2020). Frailty and comprehensive geriatric assessment. Journal of Korean Medical Science, 35(3), e16. https://doi.org/10.3346/jkms.2020.35.e16eISSN1598-6357·pISSN1011-8934

Lewin, K. (1951). Field theory in social science: selected theoretical papers (Edited by Dorwin Cartwright.). Harpers.

Liu, H., Shang, N., Chhetri, J. K., Liu, L., Guo, W., Li, P., Guo, S., \& Ma, L. (2020). A Frailty Screening Questionnaire (FSQ) to rapidly predict negative health outcomes of older adults in emergency care settings. The Journal of Nutrition, Health and Aging, 24(6), 627-633. https://dx.doi.org./10.1007/s12603-020-1374-8 
Maxwell, C. A., Dietric, M. A., \& Miller, R. S. (2018). The FRAIL Questionnaire: A useful tool for bedside screening of geriatric trauma patients. Journal of Trauma Nursing, 25(4), 242-247. https://doi.org/10.1097/JTN.0000000000000379

Maxwell, C. A., Patel, M. B., Suarez-Rodriguez, L. C., \& Miller, R. S. (2019). Frailty and prognostication in geriatric surgery and trauma. Clinics in Geriatric Medicine, 35(1), 13-26. https://doi.org/10.1016/j.cger.2018.08.002

Moreno-Arino, M., Jimenez, I. T., Gutierrez, A. C., Morera, J. C. O., \& Comet, R. (2020). Assessing the strengths and weakness of the Clinical Frailty Scale through correlation with a frailty index. Aging Clinician and Experimental Research, 32, 2225-2232. https://doi.org/10.1007/s40520-019-01450-w

Morley, J. E., Vellas, B., van Kan, G. A., Anker, S. D., Bauer, J. M., Bernabei, R., Cesari, M., Chumlea, W. C., Doehner, W., Evans, J., Fried, L. P., Guralnik, J. M., Katz, P. R., Malmstrom, T. K., McCarter, R. J., Gutierrez Robledo, L. M., Rockwood, K., von Haehling, S., Vandewoude, M. F., \& Walston, J. (2013). Frailty consensus: A call to action. Journal of the American Medical Directors Association, 14(6), 392-397. https://doi.org/10.1016/j.jamda.2013.03.022

Nguyen, T. N., Cumming, R. G., \& Hilmer, S. N. (2015). The impact of frailty on mortality, length of stay, and rehospitalization in older patients with atrial fibrillation. Heart, Lung, and Circulation, 25(6), 551-557. http://dx.doi.org/10.1016/j.hlc.2015.12.002

Nurses Improving Care for Healthsystem Elders. (2021). Mission. https://nicheprogram.org/about/mission

Office for Civil Rights. (2012, Nov 26). Guidance regarding methods for de-identification of protected health information in accordance with the Health Insurance Portability and 
Accountability Act (HIPAA) Privacy rule. U.S. Department of Health and Human Services.

https://www.hhs.gov/sites/default/files/ocr/privacy/hipaa/understanding/coveredentities/D e-identification/hhs_deid_guidance.pdf

Pugh, R. J., Battle, C. E., Thorpe, C., Lynch, C., Williams, J. P., Campbell, A., Subbe, C. P., Whitaker, R., Szakmany, T., Clegg, A. P., \& Lone, N. I. (2019). Reliability of frailty assessment in the critically ill: A multicenter prospective observation study. Anaesthesia, 74, 758-764. https://doi.org/10.111/anae.14596

Ritt, M., Gaßmann, K. G., \& Sieber, C. C. (2016). Significance of frailty for predicting adverse clinical outcomes in different patient groups with specific medical conditions. Zeitschrift fur Gerontologie und Geriatrie, 49(7), 567-572. https://doi.org/10.1007/s00391-016$1128-8$

Simpson, K. N., Seamon, B. A., Hand, B. N., Roldan, C. O., Taber, D. J., Moran, W. P., \& Simpson, A. N. (2018). Effect of frailty on resource use and cost for Medicare patients. Journal of Comparative Effectiveness Research, 7(8), 817-825. https://doi.org/10.2217/cer-2018-0029

Taffet, G. E. (2019). Normal aging. UpToDate. Retrieved January 1, 2021, from https://www.uptodate.com/contents/normal-aging

Theou, O., Squires, E., Mallery, K., Lee, J. S., Fay, S., Goldstein, J., Armstrong, J. J., \& Rockwood, K. (2018). What do we know about frailty in the acute care setting? A scoping review. BMC Geriatrics, 18(1), 139. https://doi.org/10.1186/s12877-018-0823-2

Torsney, K. M. \& Romero-Ortuno, R. (2018). The Clinical Frailty Scale predicts inpatient mortality in older hospitalized patients with idiopathic Parkinson's disease. Journal of the 
Royal College of Physicians of Edinburgh, 48, 103-107.

https://doi.org/10.4997/JRCPE.2018.201

U.S. Census Bureau. (2020, June 25). 65 and older population grows rapidly as baby boomers age [Press release]. https://www.census.gov/newsroom/press-releases/2020/65-olderpopulation-grows.html

University of Virginia Health. (2020). Mission, values, \& goals. https://uvahealth.com/about/mission

Walston, J., Buta, B., \& Xue, Q. (2018). Frailty screenings and interventions: Considerations for clinical practice. Clinics in Geriatric Medicine, 34(1), 25-38. https://doi.org/10.1016/j.cger.2017.09.004

White, K. M., Dudley-Brown, S., \& Terhaar, M. F. (2021). Translation of evidence into nursing and healthcare ( ${ }^{\text {rd }}$ Ed.). Springer Publishing Company, LLC.

Woods, N. F., LaCroix, A. Z., Gray, S. L., Aragaki, A., Cochrane, B. B., Brunner, R. L., Masaki, K., Murray, A., \& Newman, A. B. (2005). Frailty: Emergence and consequences in women aged 65 and older in the Women's Health Initiative Observational Study. Journal of the American Geriatrics Society, 53(5), 1321-1330. https://doi.org/10.1111/j.15325415.2005.53405.x

Xue, Q. L. (2011). The frailty syndrome: Definition and natural history. Clinics in Geriatric Medicine, 27(1), 1-15. https://doi.org/10.1016/j.cger.2010.08.009

Zaccagnini, M. E., \& White, K. W. (2014). The doctor of nursing practice essentials: A new model for advanced practice nursing ( $2^{\text {nd }}$ Ed.). Jones \& Bartlett Learning.

Zhao, F., Tang, B., Hu, C., Wang, B., Wang, Y., \& Zhang, L. (2020). The impact of frailty on posttraumatic outcomes in older trauma patients: A systematic review and meta- 
analysis. The Journal of Trauma and Acute Care Surgery, 88(4), 546-554.

https://doi.org/10.1097/TA.0000000000002583 


\section{Table 1}

Frailty Screening Tool Themes

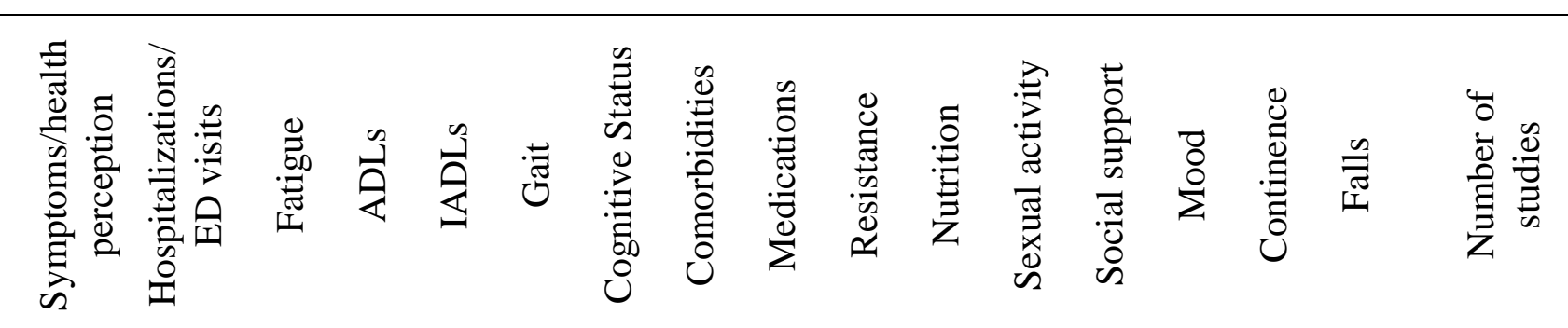

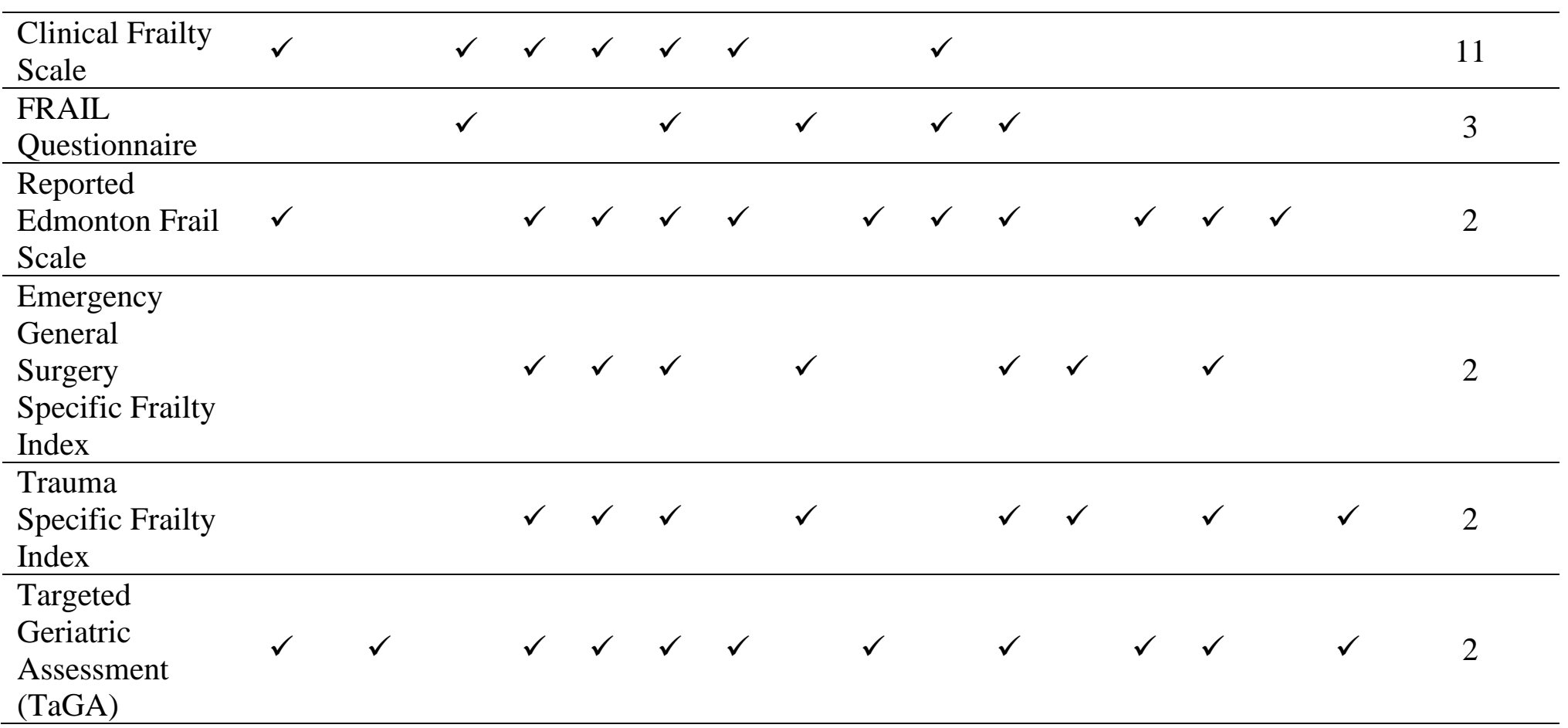




\section{Table 2}

Geriatric Frailty Screening: Lewin's Change Theory and Johns Hopkins Nursing Evidence-Based Practice Model

\begin{tabular}{|c|c|c|c|}
\hline $\begin{array}{l}\text { Lewin's } \\
\text { change theory }\end{array}$ & $\begin{array}{l}\text { JHNEBP } \\
\text { 3-step } \\
\text { process }\end{array}$ & JHNEBP Activities & Project manager activity summary \\
\hline \multirow[t]{2}{*}{ Unfreeze } & $\begin{array}{l}\text { Practice } \\
\text { question }\end{array}$ & $\begin{array}{l}\text { Step 1: Recruit interprofessional team } \\
\text { Step 2: Define the problem } \\
\text { Step 3: Develop and refine the EBP question } \\
\text { Step 4: Identify stakeholders } \\
\text { Step 5: Determine responsibility for project leadership } \\
\text { Step 6: Schedule team meetings }\end{array}$ & $\begin{array}{l}\text { Consult interprofessional clinical leaders for } \\
\text { geriatric frailty current practices and opportunity } \\
\text { to implement evidence-based practice. } \\
\text { Stakeholders identified nurses, physicians, } \\
\text { physical therapy, occupational therapy, social } \\
\text { work, nutrition. }\end{array}$ \\
\hline & Translation & $\begin{array}{l}\text { Step 12: Determine fit, feasibility, and appropriateness of } \\
\text { recommendation(s) for translation path }\end{array}$ & $\begin{array}{l}\text { Action plan developed and geriatric frailty } \\
\text { screening pilot implemented on acute care }\end{array}$ \\
\hline
\end{tabular}

Note: This table reflects the EBP project's steps aligned with the three stages of change in Lewin's change theory and the JHNEBP

three-step process and activities (Lewin, 1951; Dang \& Dearholt, 2017). 


\section{Table 3}

Geriatric Frailty Screening EBP Project Budget

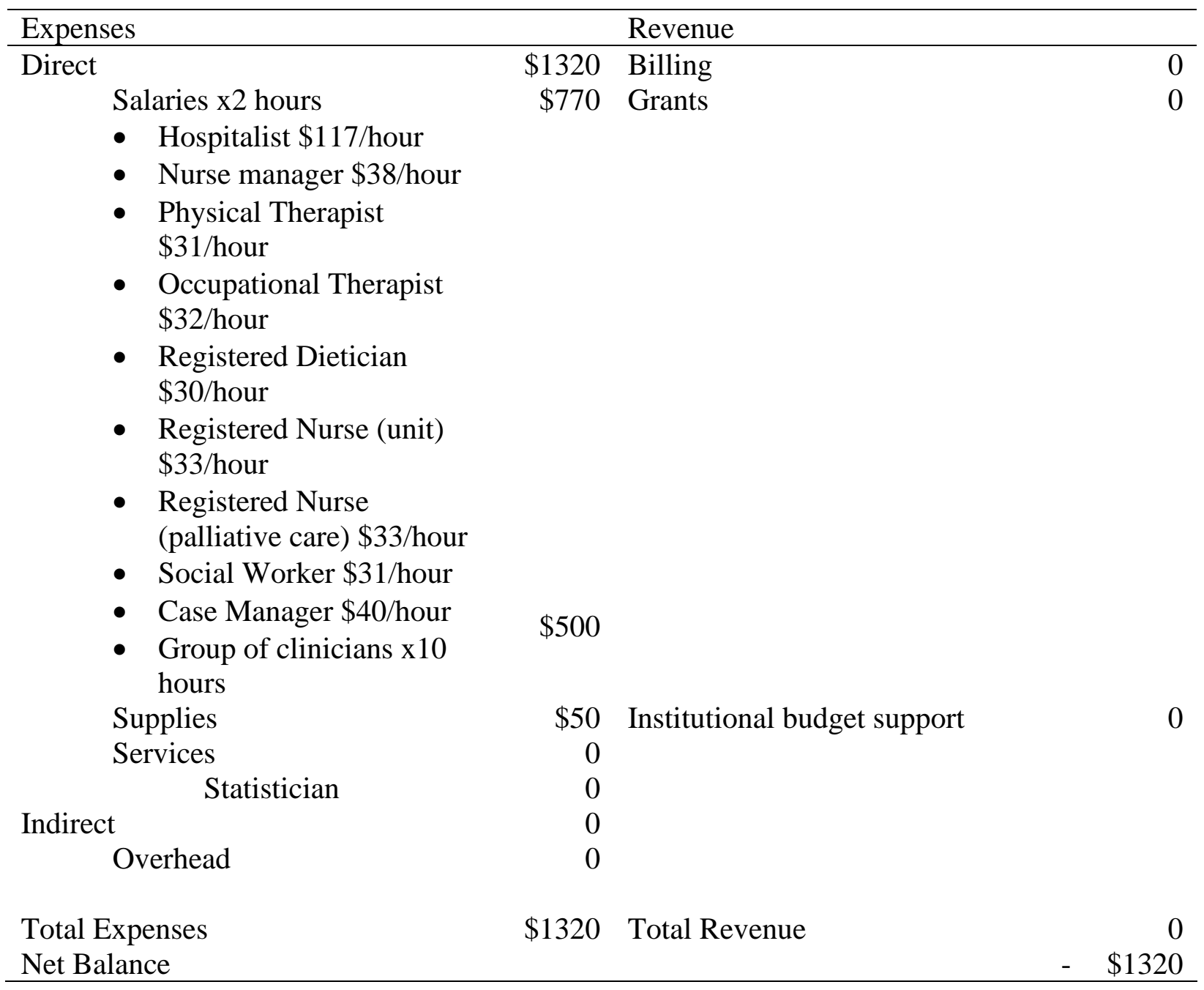




\section{Table 4}

Data Analysis

\begin{tabular}{|c|c|c|c|c|c|c|c|}
\hline Data element & $\begin{array}{l}\text { Outcome } \\
\text { measures }\end{array}$ & $\begin{array}{l}\text { Process } \\
\text { measure }\end{array}$ & $\begin{array}{c}\text { Balancing } \\
\text { measure }\end{array}$ & $\begin{array}{c}\text { Financial } \\
\text { measure }\end{array}$ & $\begin{array}{c}\text { Sustainability } \\
\text { measure }\end{array}$ & $\begin{array}{l}\text { Level of } \\
\text { measure }\end{array}$ & Test \\
\hline $\begin{array}{l}\text { Clinical Frailty } \\
\text { Scale (ID) }\end{array}$ & $\mathrm{X}$ & & & & & Scale & N/A \\
\hline Age & & & & & & Scale & N/A \\
\hline CFS appropriate & & $X$ & $X$ & & $X$ & Nominal & N/A \\
\hline CFS completion & & $X$ & $X$ & $X$ & $X$ & Nominal & $\mathrm{CS}, \mathrm{FE}$ \\
\hline $\begin{array}{l}\text { Was personalized } \\
\text { plan of care } \\
\text { created/modified? }\end{array}$ & $X$ & X & $X$ & $X$ & $X$ & Nominal & $\mathrm{CS}, \mathrm{FE}$ \\
\hline
\end{tabular}

Note: ID, independent variable; CS, chi-square test of independence; FE, Fisher's exact test 


\section{Table 5}

Means and Statistical Deviation on the Measures of Age and Clinical Frailty Scale

\begin{tabular}{lccccc}
\hline Variable & $M$ & $S D$ & $n$ & Min & Max \\
\hline Age & 75.33 & 7.31 & 40 & 65 & 92 \\
CFS score & 5.56 & 1.78 & 36 & 3 & 9 \\
\hline
\end{tabular}




\section{Table 6}

Chi-square Test: Observed and Expected Frequencies

\begin{tabular}{|c|c|c|c|c|c|}
\hline \multirow[b]{2}{*}{ Completed } & \multicolumn{2}{|c|}{ Plan of Care } & \multirow[b]{2}{*}{$\chi^{2}$} & \multirow[b]{2}{*}{$d f$} & \multirow[b]{2}{*}{$p$} \\
\hline & Adjusted & Not adjusted & & & \\
\hline Completed & $35[32.40]$ & $1[3.60]$ & 20.86 & 1 & $<.001$ \\
\hline Not completed & $1[3.60]$ & $3[0.40]$ & & & \\
\hline
\end{tabular}

Note. Values formatted as Observed [Expected]. 
Table 7

Fisher Exact Test: Observed and Expected Frequencies

\begin{tabular}{lcccc}
\hline & \multicolumn{3}{c}{ Completed } & \\
\cline { 2 - 4 } Plan of Care & Completed & Not completed & OR & $p$ \\
Adjusted & $35[32.40]$ & $1[3.60]$ & 68.12 & .002 \\
Not adjusted & $1[3.60]$ & $3[0.40]$ & & \\
\hline
\end{tabular}

Note. Values formatted as Observed [Expected]. 


\section{Figure 1}

PRISMA
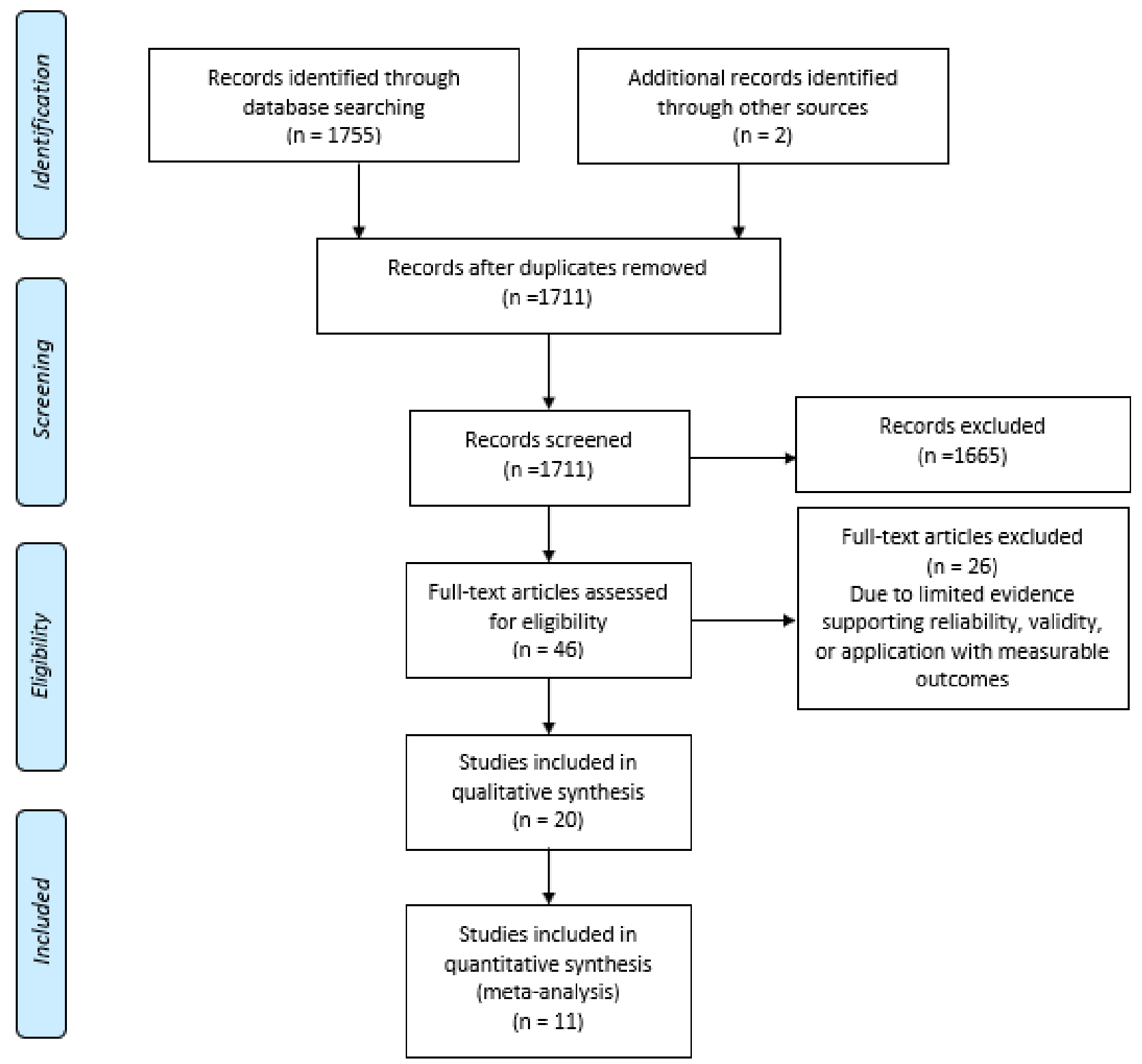

Note: Adapted from: "Preferred Reporting Items for Systematic Reviews and Meta-Analyses: The PRISMA Statement," by D. Moher, A. Liberati, J.Tetzlaff, and D. G. Altman, PLoS Med 6(7): e1000097 (doi:10.1371/journal.pmed1000097). Copyright 2009 by The PRISMA Group. 


\section{Appendix A}

Summary of Primary Research Evidence

\begin{tabular}{|c|c|c|c|c|c|c|c|}
\hline Citation & Design & $\begin{array}{l}\text { Evidence } \\
\text { level } \\
\text { Quality } \\
\text { Grade }\end{array}$ & $\begin{array}{l}\text { Sample (size, } \\
\text { demographics, } \\
\text { location) }\end{array}$ & $\begin{array}{l}\text { Intervention } \\
\text { (definitions for any } \\
\text { tool w/ } \\
\text { reliability/validity) }\end{array}$ & Comparison & $\begin{array}{l}\text { Outcomes } \\
\text { Intervention vs } \\
\text { comparison } \\
--- \\
\text { Other outcomes of } \\
\text { interest }\end{array}$ & $\begin{array}{l}\text { Results, Key } \\
\text { Findings }\end{array}$ \\
\hline \multicolumn{8}{|c|}{ Clinical Frailty Scale (CFS) } \\
\hline $\begin{array}{l}\text { Curtis, } \\
\text { E., et al. } \\
(2018) \text {. }\end{array}$ & $\begin{array}{l}\text { Retrospective } \\
\text { review }\end{array}$ & $\begin{array}{l}\text { Level III } \\
\text { Quality A }\end{array}$ & $\begin{array}{l}\text { Sample: } 1635 \\
\text { geriatric }(65+ \\
\text { years old) } \\
\text { patients } \\
\text { admitted with } \\
\text { trauma injuries } \\
\text { Age: } 77.6 \pm 8.6 \\
\text { years } \\
\text { Location: } \\
\text { United States } \\
\text { (California) }\end{array}$ & $\begin{array}{l}\text { Retrospective } \\
\text { electronic medical } \\
\text { record: *Clinical } \\
\text { Frailty Scale (CFS) } \\
\text { score }\end{array}$ & $\begin{array}{l}\text { Age, } \\
\text { Glasgow } \\
\text { Coma Scale, } \\
\text { Systolic } \\
\text { Blood } \\
\text { Pressure }\end{array}$ & $\begin{array}{l}\text { Predictive value to } \\
\text { hospital mortality or } \\
\text { discharge to skilled } \\
\text { nursing facility: } \\
\text { Discharge vs death: } \\
\text { Frailty }(1.23)>\text { age } \\
(1.04), \text { GCS }(0.7) \text {, } \\
\text { SBP }(0.98) \\
\text { Skilled nursing } \\
\text { disposition: Frailty } \\
(1.54)>\text { age }(1.06) \text {, } \\
\text { GCS }(0.81), \text { SBP } \\
(0.99)\end{array}$ & $\begin{array}{l}\text { CFS is a } \\
\text { significant } \\
\text { predictor of } \\
\text { mortality and } \\
\text { discharge to } \\
\text { SNF }\end{array}$ \\
\hline $\begin{array}{l}\text { Pugh, R. } \\
\text { J., et al. } \\
(2019) \text {. }\end{array}$ & $\begin{array}{l}\text { Prospective } \\
\text { observational } \\
\text { study }\end{array}$ & $\begin{array}{l}\text { Level III } \\
\text { Quality B }\end{array}$ & $\begin{array}{l}\text { Sample: } 101 \\
\text { geriatric } \\
\text { patients } \\
\text { admitted to } \\
\text { critical care } \\
\text { units across six } \\
\text { hospitals } \\
\text { Age: average } 69 \\
\text { years old }\end{array}$ & $\begin{array}{l}\text { Clinical Frailty } \\
\text { Scale (CFS) scoring } \\
\text { interrater reliability }\end{array}$ & None & $\begin{array}{l}\text { Full agreement in } \\
53 \% \text { of patient } \\
\text { scoring } \\
\text { Disagreement of } 1 \\
\text { CFS category: } 40 \% \\
\text { Disagreement of } 2 \\
\text { CFS category: } 5 \% \\
\text { Disagreement of } 3 \\
\text { CFS category: } 2 \%\end{array}$ & $\begin{array}{l}\text { "Good" level } \\
\text { of interrater } \\
\text { reliability }\end{array}$ \\
\hline
\end{tabular}




\begin{tabular}{|c|c|c|c|c|c|c|c|}
\hline & & & $\begin{array}{l}\text { Location: Wales } \\
\text { and Scotland }\end{array}$ & & & & \\
\hline $\begin{array}{l}\text { Cheung, } \\
\text { A., et al. } \\
(2017) \text {. }\end{array}$ & $\begin{array}{l}\text { Retrospective } \\
\text { cohort }\end{array}$ & $\begin{array}{l}\text { Level III } \\
\text { Quality A }\end{array}$ & $\begin{array}{l}\text { Sample: } 266 \\
\text { geriatric } \\
\text { patients } \\
\text { admitted with } \\
\text { trauma injuries } \\
\text { Age: } 76.5 \pm 7.8 \\
\text { years } \\
\text { Location: } \\
\text { Ontario }\end{array}$ & $\begin{array}{l}\text { Clinical Frailty } \\
\text { Scale (CFS) }\end{array}$ & FI-laboratory & $\begin{array}{l}\text { Predictive value to } \\
\text { adverse discharge: } \\
\text { CFS frail }(71.4 \%)> \\
\text { CFS not frail } \\
(28.4 \%) \\
\text { FI-labs did not } \\
\text { correlate with pre- } \\
\text { admission } \\
\text { frailty/CFS or } \\
\text { adverse discharge }\end{array}$ & $\begin{array}{l}\text { CFS is a } \\
\text { significant } \\
\text { predictor of } \\
\text { adverse } \\
\text { discharge }\end{array}$ \\
\hline $\begin{array}{l}\text { Liu, H., } \\
\text { et al. } \\
(2020) .\end{array}$ & $\begin{array}{l}\text { Observational } \\
\text { study }\end{array}$ & $\begin{array}{l}\text { Level III } \\
\text { Quality A }\end{array}$ & $\begin{array}{l}\text { Sample: } 350 \\
\text { geriatric } \\
\text { patients } \\
\text { admitted to the } \\
\text { Emergency } \\
\text { Department } \\
\text { Age: } \\
78.77 \pm 9.57 \\
\text { years } \\
\text { Location: } \\
\text { Beijing }\end{array}$ & $\begin{array}{l}\text { Frailty Screening } \\
\text { Questionnaire (FSQ) }\end{array}$ & $\begin{array}{l}\text { Clinical } \\
\text { Frailty } \\
\text { Screening } \\
\text { (CFS) }\end{array}$ & $\begin{array}{l}\text { Positive correlation } \\
\text { between FSQ and } \\
\text { CFS }\end{array}$ & $\begin{array}{l}\text { FSQ is a } \\
\text { more rapid } \\
\text { screening } \\
\text { than CFS }\end{array}$ \\
\hline $\begin{array}{l}\text { Brumme } \\
\text { 1, N. E., } \\
\text { et al. } \\
(2017) \text {. }\end{array}$ & $\begin{array}{l}\text { Prospective } \\
\text { cohort study }\end{array}$ & $\begin{array}{l}\text { Level III } \\
\text { Quality A }\end{array}$ & $\begin{array}{l}\text { Sample: } 1040 \\
\text { patients } \\
\text { admitted w/ } \\
\text { respiratory } \\
\text { failure or shock } \\
\text { to medical or } \\
\text { surgical ICUs } \\
\text { Age: } 62 \text { years } \\
\text { Location: } \\
\text { United States }\end{array}$ & $\begin{array}{l}\text { Clinical Frailty } \\
\text { Scale (CFS) }\end{array}$ & None & $\begin{array}{l}\text { Predictive value to } \\
12 \text {-month mortality } \\
\text { (50\% in those with } \\
\text { higher CFS), } \\
\text { disability ( } 30 \% \text { in } \\
\text { higher CFS), lower } \\
\text { quality of life }\end{array}$ & $\begin{array}{l}\text { Risk of poor } \\
\text { outcomes } \\
\text { increased } \\
\text { with poor } \\
\text { CFS scores }\end{array}$ \\
\hline
\end{tabular}




\begin{tabular}{|c|c|c|c|c|c|c|c|}
\hline $\begin{array}{l}\text { Flaatten, } \\
\text { H., et al. } \\
(2017) .\end{array}$ & $\begin{array}{l}\text { Prospective } \\
\text { cohort study }\end{array}$ & $\begin{array}{l}\text { Level III } \\
\text { Quality A }\end{array}$ & $\begin{array}{l}\text { Sample: } 5021 \\
\text { geriatric } \\
\text { patients } 80+ \\
\text { years old } \\
\text { admitted ICUs } \\
\text { Age: median } \\
\text { age } 84 \text { years old } \\
\text { Location: } 21 \\
\text { European } \\
\text { countries } \\
\text { (European } \\
\text { Society of } \\
\text { Intensive Care } \\
\text { Medicine) }\end{array}$ & $\begin{array}{l}\text { Clinical Frailty } \\
\text { Scale (CFS) }\end{array}$ & $\begin{array}{l}\text { SOFA score, } \\
\text { gender, age }\end{array}$ & $\begin{array}{l}\text { Predictive value for } \\
\text { 30-day survival: } \\
\text { higher CFS < lower } \\
\text { CFS ( } 76 \% \text { mortality } \\
\text { vs. 59\%) } \\
\text { Withheld or } \\
\text { withdrawn care: } \\
\text { higher CFS > lower } \\
\text { CFS (31.3\% and } \\
14.8 \% \text { vs. } 14.2 \% \\
\text { and } 9.9 \%)\end{array}$ & $\begin{array}{l}\text { CFS is a } \\
\text { significant } \\
\text { predictor of } \\
\text { ICU } \\
\text { mortality and } \\
\text { 30-day } \\
\text { mortality }\end{array}$ \\
\hline $\begin{array}{l}\text { Torsney, } \\
\text { K. M. et } \\
\text { al. } \\
\text { (2018). }\end{array}$ & $\begin{array}{l}\text { Observational } \\
\text { retrospective }\end{array}$ & $\begin{array}{l}\text { Level III } \\
\text { Quality A }\end{array}$ & $\begin{array}{l}\text { Sample: } 393 \\
\text { Parkinson's } \\
\text { disease patients } \\
75 \text { years old } \\
\text { with first } \\
\text { admissions } \\
\text { Age: } 82.8 \pm 5 \\
\text { years } \\
\text { Location: } \\
\text { United } \\
\text { Kingdom }\end{array}$ & $\begin{array}{l}\text { Clinical Frailty } \\
\text { Scale (CFS) }\end{array}$ & $\begin{array}{l}\text { Charlson } \\
\text { Comorbidity } \\
\text { Index (CCI) }\end{array}$ & $\begin{array}{l}\text { Predictive value for } \\
\text { inpatient mortality: } \\
\text { CFS 7-9 Odds Ratio } \\
(8.14)>\text { CFS 5-6 } \\
(2.46) \\
\text { CCI was not } \\
\text { associated with } \\
\text { mortality }\end{array}$ & $\begin{array}{l}\text { CFS is a } \\
\text { significant } \\
\text { predictor of } \\
\text { mortality in } \\
\text { elder } \\
\text { inpatients } \\
\text { with } \\
\text { Parkinson's } \\
\text { Disease }\end{array}$ \\
\hline $\begin{array}{l}\text { Chong, } \\
\text { E., et al. } \\
(2019) \text {. }\end{array}$ & $\begin{array}{l}\text { Retrospective } \\
\text { review }\end{array}$ & $\begin{array}{l}\text { Level III } \\
\text { Quality C }\end{array}$ & $\begin{array}{l}\text { Sample: } 210 \\
\text { geriatric } \\
\text { inpatients } \\
\text { Age: } 89.4 \text { years } \\
\text { old } \\
\text { Race: not stated } \\
\text { Location: } \\
\text { Singapore }\end{array}$ & $\begin{array}{l}\text { Clinical Frailty } \\
\text { Scale algorithm } \\
\text { (CFS-A) }\end{array}$ & & $\begin{array}{l}\text { Predictive value for } \\
\text { frailty: CFS-A } \\
(96 \%)>\text { CFS }(81 \%)\end{array}$ & $\begin{array}{l}\text { CFS-A has } \\
\text { excellent } \\
\text { interrater } \\
\text { agreement }\end{array}$ \\
\hline
\end{tabular}




\begin{tabular}{|c|c|c|c|c|c|c|c|}
\hline $\begin{array}{l}\text { Chong, } \\
\text { E., et al. } \\
(2017) \text {. }\end{array}$ & $\begin{array}{l}\text { Prospective } \\
\text { cohort study }\end{array}$ & $\begin{array}{l}\text { Level III } \\
\text { Quality A }\end{array}$ & $\begin{array}{l}\text { Sample: } 210 \\
\text { geriatric } \\
\text { inpatients } \\
\text { Age: } 89.4 \text { years } \\
\text { old } \\
\text { Location: } \\
\text { Singapore }\end{array}$ & $\begin{array}{l}\text { Clinical Frailty } \\
\text { Scale (CFS) }\end{array}$ & $\begin{array}{l}\text { Frailty Index, } \\
\text { FRAIL, and } \\
\text { Tilburg } \\
\text { Frailty } \\
\text { Indicator } \\
\text { (TFI) }\end{array}$ & $\begin{array}{l}\text { Predictive value for } \\
\text { inpatient mortality } \\
\text { (\%): FRAIL > FI, } \\
\text { TFI, and CFS ( } 6.7 \text { vs } \\
5.14 .8 \text { vs } 4.7) \text {. } \\
\text { Predictive value for } \\
\text { increased LOS: } \\
\text { FRAIL > CFS ( } 10 \\
\text { vs. } 8 \text { ) } \\
\text { Predictive value for } \\
\text { 12-month mortality } \\
\text { (\%): CFS > FI, } \\
\text { FRAIL, TFI (32.9 } \\
\text { vs. 30.6 vs. } 32.4 \text { vs. } \\
\text { 23.2) } \\
\text { Predictive value for } \\
\text { 12-month } \\
\text { institutionalization } \\
\text { (\%): CFS > FI, } \\
\text { FRAIL, TFI (38.7 } \\
\text { vs. 36.5 vs. } 46.7 \text { vs. } \\
\text { 37.1) }\end{array}$ & $\begin{array}{l}\text { FRAIL tool } \\
\text { had lower } \\
\text { detection rate } \\
\text { of frailty. } \\
\text { CFS is a } \\
\text { significant } \\
\text { predictor of } \\
12 \text {-month } \\
\text { mortality and } \\
\text { institutionali } \\
\text { zation. }\end{array}$ \\
\hline $\begin{array}{l}\text { Moreno- } \\
\text { Arino, } \\
\text { M., et } \\
\text { al. } \\
(2020) \text {. }\end{array}$ & $\begin{array}{l}\text { Observational } \\
\text { Cross- } \\
\text { sectional } \\
\text { descriptive } \\
\text { study }\end{array}$ & $\begin{array}{l}\text { Level III } \\
\text { Quality A }\end{array}$ & $\begin{array}{l}\text { Sample: } 184 \\
\text { geriatric } \\
\text { inpatients } \\
\text { Age: } 85.35 \\
\text { years old } \\
\text { Race: not stated } \\
\text { Location: Spain }\end{array}$ & $\begin{array}{l}\text { Clinical Frailty } \\
\text { Scale (CFS) }\end{array}$ & IF-VIG*** & $\begin{array}{l}\text { Predictive value for } \\
\text { frailty: CFS = IF- } \\
\text { VIG }\end{array}$ & $\begin{array}{l}\text { CFS is a } \\
\text { streamlined } \\
\text { and efficient } \\
\text { tool to } \\
\text { initially } \\
\text { identify } \\
\text { frailty. }\end{array}$ \\
\hline $\begin{array}{l}\text { Ellis, H. } \\
\text { L., et al. } \\
(2020) \text {. }\end{array}$ & $\begin{array}{l}\text { Prospective } \\
\text { cohort }\end{array}$ & $\begin{array}{l}\text { Level III } \\
\text { Quality B }\end{array}$ & $\begin{array}{l}\text { Sample: } 1750 \\
\text { geriatric } \\
\text { inpatients }\end{array}$ & $\begin{array}{l}\text { Clinical Frailty } \\
\text { Scale (CFS) }\end{array}$ & $\begin{array}{l}\text { FI- } \\
\text { Laboratory }\end{array}$ & $\begin{array}{l}\text { FI-Laboratory } \\
\text { correlated weakly } \\
\text { with the CFS }\end{array}$ & $\begin{array}{l}\text { CFS is a } \\
\text { significant } \\
\text { predictor of } \\
\text { longer length }\end{array}$ \\
\hline
\end{tabular}




\begin{tabular}{|c|c|c|c|c|c|c|c|}
\hline & & & $\begin{array}{l}\text { Age: } 84.8 \text { years } \\
\text { old } \\
\text { Location: } \\
\text { United } \\
\text { Kingdom }\end{array}$ & & & $\begin{array}{l}\text { Predictive value for } \\
\text { higher CFS and FI- } \\
\text { Laboratory values in } \\
\text { longer length of } \\
\text { stay, higher level of } \\
\text { care at discharge, } \\
\text { readmission }\end{array}$ & $\begin{array}{l}\text { of stay, } \\
\text { higher level } \\
\text { of care at } \\
\text { discharge, } \\
\text { readmission } \\
\text { (unclear } \\
\text { advantage of } \\
\text { FI- } \\
\text { laboratory) }\end{array}$ \\
\hline \multicolumn{8}{|c|}{ FRAIL Questionnaire } \\
\hline $\begin{array}{l}\text { Maxwell } \\
\text {, C. A., } \\
\text { et al. } \\
\text { (2018). }\end{array}$ & $\begin{array}{l}\text { Retrospective } \\
\text { review }\end{array}$ & $\begin{array}{l}\text { Level III } \\
\text { Quality B }\end{array}$ & $\begin{array}{l}\text { Sample: } 188 \\
\text { geriatric trauma } \\
\text { inpatients } \\
\text { Age: } 77 \text { years } \\
\text { old } \\
\text { Location: } \\
\text { United States } \\
\text { (Tennessee) }\end{array}$ & $\begin{array}{l}\text { FRAIL } \\
\text { Questionnaire }\end{array}$ & $\begin{array}{l}\text { Age, severity } \\
\text { of injury }\end{array}$ & $\begin{array}{l}\text { Predictive value for } \\
\text { higher FRAIL score } \\
\text { in } 12 \text {-month } \\
\text { mortality: FRAIL > } \\
\text { age, severity of } \\
\text { injury ( } 74 \% \text { increase } \\
\text { for each point vs. } \\
7 \% \text { increase for age } \\
\text { vs. } 68 \% \text { increase for } \\
\text { injury severity point) }\end{array}$ & $\begin{array}{l}\text { FRAIL score } \\
\text { is a } \\
\text { significant } \\
\text { predictor of } \\
12 \text {-month } \\
\text { mortality. }\end{array}$ \\
\hline $\begin{array}{l}\text { Apraha } \\
\text { mian, I., } \\
\text { et al. } \\
\text { (2018). } \\
\text { https://d } \\
\text { oi.org/1 } \\
0.1016 / \text { j. } \\
\text { archger. } \\
2018.04 \text {. } \\
005\end{array}$ & $\begin{array}{l}\text { Prospective } \\
\text { cohort study }\end{array}$ & $\begin{array}{l}\text { Level III } \\
\text { Quality B }\end{array}$ & $\begin{array}{l}\text { Sample: } 701 \\
\text { geriatric } \\
\text { inpatients } \\
\text { Age: } 79.5 \text { years } \\
\text { old } \\
\text { Location: Brazil }\end{array}$ & $\begin{array}{l}\text { FRAIL } \\
\text { Questionnaire }\end{array}$ & $\begin{array}{l}\text { Cognitive } \\
\text { screening }\end{array}$ & $\begin{array}{l}\text { FRAIL tool had } \\
\text { lower detection rate } \\
\text { of frailty in } \\
\text { cognitively impaired } \\
\text { patients. } \\
\text { Predictive value for } \\
\text { frailty of FRAIL < } \\
\text { FRAIL + cognitive } \\
\text { status ( } 36.7 \text { frail vs } \\
46.6 \% \text { frail + } \\
\text { cognitive } \\
\text { impairment). }\end{array}$ & $\begin{array}{l}\text { FRAIL tool } \\
\text { supplemente } \\
d \text { with } \\
\text { cognitive } \\
\text { function } \\
\text { scoring is a } \\
\text { predictor of } \\
\text { frailty and } \\
\text { 12-month } \\
\text { mortality. }\end{array}$ \\
\hline
\end{tabular}




\begin{tabular}{|c|c|c|c|c|c|c|c|}
\hline $\begin{array}{l}\text { Ibrahim, } \\
\text { K., et al. } \\
(2019) \text {. }\end{array}$ & $\begin{array}{l}\text { Cross- } \\
\text { sectional } \\
\text { prospective } \\
\text { study }\end{array}$ & $\begin{array}{l}\text { Level III } \\
\text { Quality B }\end{array}$ & $\begin{array}{l}\text { Sample: } 239 \\
\text { geriatric } \\
\text { inpatients } \\
\text { Age: } 80 \text { years } \\
\text { old } \\
\text { Location: } \\
\text { England }\end{array}$ & $\begin{array}{l}\text { FRAIL } \\
\text { Questionnaire }\end{array}$ & $\begin{array}{l}\text { Fried Frailty } \\
\text { Phenotype }\end{array}$ & $\begin{array}{l}\text { Predictive value for } \\
\text { frailty: FRAIL < } \\
\text { Fried Frailty } \\
\text { Phenotype ( } 34 \% \text { vs. } \\
48 \% \text { ). } \\
\text { Gait speed not able } \\
\text { to be assessed in } \\
70 \% \text { and muscle } \\
\text { mass not able to be } \\
\text { assessed in } 50 \% \text {. }\end{array}$ & $\begin{array}{l}\text { No } \\
\text { recommendat } \\
\text { ions. }\end{array}$ \\
\hline \multicolumn{8}{|c|}{ Emergency General Surgery Specific Frailty Index, Trauma Specific Frailty Index } \\
\hline $\begin{array}{l}\text { Engelha } \\
\text { rdt, K. } \\
\text { E., et al. } \\
(2018) .\end{array}$ & $\begin{array}{l}\text { Prospective } \\
\text { cohort study }\end{array}$ & $\begin{array}{l}\text { Level V } \\
\text { Quality B }\end{array}$ & $\begin{array}{l}\text { Sample: } 70 \\
\text { geriatric } \\
\text { trauma/emergen } \\
\text { cy general } \\
\text { surgery } \\
\text { inpatients } \\
\text { Age: } 79.5 \text { years } \\
\text { old } \\
\text { Location: } \\
\text { United States } \\
\text { (Chicago, IL) }\end{array}$ & $\begin{array}{l}\text { Emergency General } \\
\text { Surgery Specific } \\
\text { Frailty Index OR } \\
\text { Trauma Specific } \\
\text { Frailty Index PLUS } \\
\text { intervention program }\end{array}$ & $\begin{array}{l}\text { No screening } \\
\text { or } \\
\text { intervention } \\
\text { program }\end{array}$ & $\begin{array}{l}\text { Screening } \\
\text { compliance: } 100 \% \\
\text { Program compliance } \\
\text { in identified frail } \\
\text { patients: } 96.6 \% \\
\text { Length of stay: } \\
\text { Screening + } \\
\text { intervention (S+I) < } \\
\text { control (6 days vs. } 9 \\
\text { days) } \\
\text { Readmissions: } \mathrm{S}+\mathrm{I}< \\
\text { control (10.2\% vs. } \\
36.4 \%) \\
\text { Loss of } \\
\text { independence: } \mathrm{S}+\mathrm{I}< \\
\text { control }(60 \% \text { vs. } \\
100 \%)\end{array}$ & $\begin{array}{l}\text { Frailty } \\
\text { screening } \\
\text { and } \\
\text { intervention } \\
\text { program } \\
\text { reduced } \\
\text { length of } \\
\text { stay, } \\
\text { readmissions, } \\
\text { and loss of } \\
\text { independenc } \\
\text { e }\end{array}$ \\
\hline $\begin{array}{l}\text { Joseph, } \\
\text { B., et al. } \\
(2014) \text {. }\end{array}$ & $\begin{array}{l}\text { Prospective } \\
\text { observational } \\
\text { study }\end{array}$ & $\begin{array}{l}\text { Level III } \\
\text { Quality B }\end{array}$ & $\begin{array}{l}\text { Sample: } 200 \\
\text { geriatric trauma } \\
\text { inpatients } \\
\text { (excluded } \\
\text { patients }\end{array}$ & $\begin{array}{l}\text { Trauma Specific } \\
\text { Frailty Index }\end{array}$ & $\begin{array}{l}\text { Age, Injury } \\
\text { Severity } \\
\text { Score }\end{array}$ & $\begin{array}{l}\text { Predictive value for } \\
\text { unfavorable } \\
\text { discharge } \\
\text { disposition: TSFI > }\end{array}$ & $\begin{array}{l}\text { TSFI is a } \\
\text { significant } \\
\text { predictor of } \\
\text { unfavorable } \\
\text { discharge }\end{array}$ \\
\hline
\end{tabular}




\begin{tabular}{|c|c|c|c|c|c|c|c|}
\hline & & & $\begin{array}{l}\text { transferred from } \\
\text { rehab, skilled } \\
\text { nursing } \\
\text { facilities, other } \\
\text { institutions) } \\
\text { Age: } 77 \text { years } \\
\text { old } \pm 12 \text { years } \\
\text { Location: } \\
\text { United States } \\
\text { (Arizona) }\end{array}$ & & & $\begin{array}{l}\text { age, Injury Severity } \\
\text { Score ( } 1.5 \text { vs. } 0)\end{array}$ & $\begin{array}{l}\text { (skilled } \\
\text { nursing } \\
\text { facility or } \\
\text { death) }\end{array}$ \\
\hline \multicolumn{8}{|c|}{ Reported Edmonton Frail Scale (REFS) } \\
\hline $\begin{array}{l}\text { Hilmer, } \\
\text { S. N., et } \\
\text { al. } \\
(2009) \text {. }\end{array}$ & $\begin{array}{l}\text { Validation } \\
\text { study }\end{array}$ & $\begin{array}{l}\text { Level III } \\
\text { Quality B }\end{array}$ & $\begin{array}{l}\text { Sample: } 111 \\
\text { geriatric acute } \\
\text { inpatients } \\
\text { Age: } 83 \text { years } \\
\text { old } \pm 7.1 \\
\text { Location: } \\
\text { Australia } \\
\text { (Sydney) }\end{array}$ & $\begin{array}{l}\text { Reported Edmonton } \\
\text { Frail Scale (REFS) }\end{array}$ & $\begin{array}{l}\text { Geriatricians } \\
\text { Clinical } \\
\text { Impression } \\
\text { of Frailty } \\
\text { (GCIF) } \\
\text { portion of } \\
\text { comprehensi } \\
\text { ve geriatric } \\
\text { assessment }\end{array}$ & $\begin{array}{l}\text { REFS demonstrated } \\
\text { satisfactory internal } \\
\text { validity (Cronbach's } \\
\text { alpha }=0.68 \text { ) and } \\
\text { excellent inter-rater } \\
\text { reliability (kappa = } \\
0.83 \text { ) } \\
\text { Moderate correlation } \\
\text { between REFS and } \\
\text { GCIF }\end{array}$ & $\begin{array}{l}\text { No } \\
\text { recommendat } \\
\text { ions }\end{array}$ \\
\hline $\begin{array}{l}\text { Hii, T. } \\
\text { B., et al. } \\
(2015) .\end{array}$ & $\begin{array}{l}\text { Prospective } \\
\text { study }\end{array}$ & $\begin{array}{l}\text { Level III } \\
\text { Quality C }\end{array}$ & $\begin{array}{l}\text { Sample: } 47 \\
\text { geriatric } \\
\text { cardiology } \\
\text { inpatients } \\
\text { Age: } 78 \text { years } \\
\text { old mean } \\
\text { Location: New } \\
\text { Zealand }\end{array}$ & $\begin{array}{l}\text { Reported Edmonton } \\
\text { Frail Scale (REFS) }\end{array}$ & $\begin{array}{l}\text { General } \\
\text { observation }\end{array}$ & $\begin{array}{l}0 \% \text { agreement } \\
\text { between general } \\
\text { observations } \\
\text { Inconsistent } \\
\text { agreement between } \\
\text { REFS }\end{array}$ & $\begin{array}{l}\text { No } \\
\text { recommendat } \\
\text { ions }\end{array}$ \\
\hline \multicolumn{8}{|c|}{ Targeted Geriatric Assessment (TaGA) } \\
\hline $\begin{array}{l}\text { Aliberti, } \\
\text { M., et }\end{array}$ & $\begin{array}{l}\text { Delphi } \\
\text { technique } \\
\text { (consensus } \\
\end{array}$ & $\begin{array}{l}\text { Level IV } \\
\text { Quality A }\end{array}$ & $\begin{array}{l}\text { Construct } \\
\text { validity } \\
\text { Sample: } 53 \\
\end{array}$ & $\begin{array}{l}\text { Targeted Geriatric } \\
\text { Assessment (TaGA) }\end{array}$ & $\begin{array}{l}\text { Frailty Index, } \\
\text { Physical } \\
\text { Frailty } \\
\end{array}$ & $\begin{array}{l}\text { Global impairment: } \\
\text { TaGA = FI }\end{array}$ & $\begin{array}{l}\text { TaGA score } \\
\text { is a rapid, } \\
\text { reliable tool }\end{array}$ \\
\hline
\end{tabular}




\begin{tabular}{|c|c|c|c|c|c|c|c|}
\hline $\begin{array}{l}\text { al. } \\
\text { (2018). }\end{array}$ & $\begin{array}{l}\text { model }=62 \\
\text { experts } \\
\text { representing } \\
32 \text { academic } \\
\text { institutions) }\end{array}$ & & $\begin{array}{l}\text { Age: } 79.5 \text { years } \\
\pm 8.4 \\
\text { Location: Brazil }\end{array}$ & & $\begin{array}{l}\text { Phenotype, } \\
\text { Identification } \\
\text { of Seniors at } \\
\text { Risk (ISAR) }\end{array}$ & $\begin{array}{l}\text { Frailty level } \\
\text { discrimination: } \\
\text { TaGA }>\text { ISAR } \\
\text { TaGA }=10 \text { health } \\
\text { domains, }<10 \\
\text { minutes } \\
\text { ISAR = 5 health } \\
\text { domains, }<10 \\
\text { minutes }\end{array}$ & $\begin{array}{l}\text { for frailty } \\
\text { screening }\end{array}$ \\
\hline
\end{tabular}

Legend:

*Clinical Frailty Scale: 7-point scale focused on overall health status and ability to perform activities of daily living (ADLs) with stratified scoring (not frail, mildly frail, moderate/severely frail, terminal); formerly called Canadian Study on health and Aging Clinical Frailty Scale.

** FRAIL Questionnaire (Fatigue, Resistance, Ambulation, Illness, and Loss of weight). Multiple cited sources of origin.

Fried Frailty Phenotype: three or more of self-reported weight loss $(>4.5 \mathrm{~kg})$ in the last 12 months, low physical activity, exhaustion, weak grip strength, and slow gait speed.

***Frail-VIG/IF-VIG: 22 question multidimensional index addressing 25 different deficits with frail/not frail scoring. 


\section{Appendix B}

Clinical Frailty Scale.

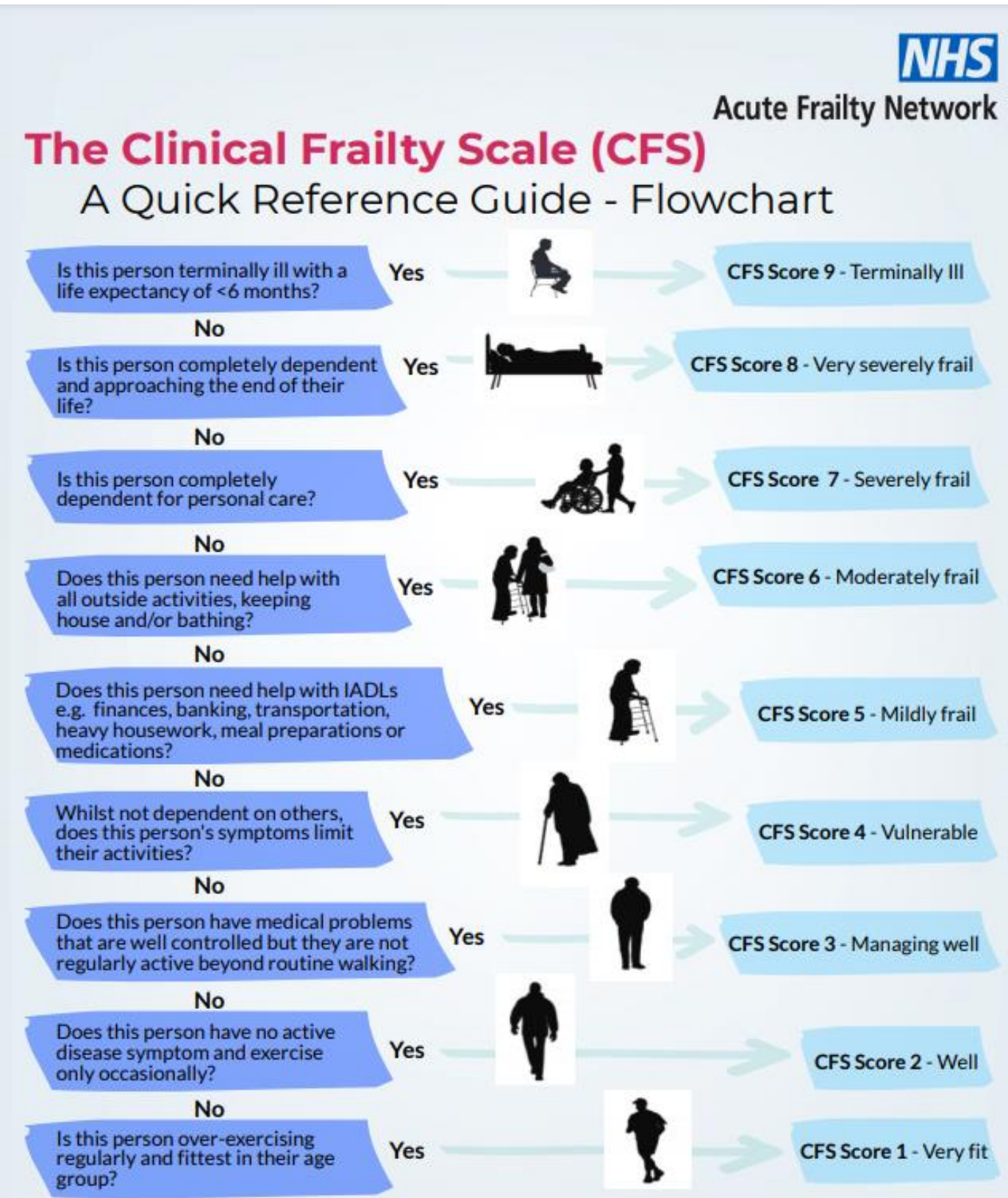

Severe Frailty CFS 7-9 Think about supportive care versus cure, advance care planning, recognition that enhanced supportive care is an active intervention in itself offering improved quality of life and, sometimes quantity of life. Comprehensive Geriatric Assessment must be completed.

Moderate Frailty CFS 6 Actively seek out and manage frailty syndromes e.g. falls, fragility fractures, cognitive impairment, continence and/or polypharmacy issues. Use the 4AT to screen for delirium in patients with dementia and/or delirium. The presence of one or more frailty syndromes should trigger Comprehensive Geriatric Assessment (CGA).

Fit/Mild Frailty CFS 1-5 Plan care as usual but address reversible issues such as sarcopenia and nutrition. Consider social prescribing and where relevant, e.g. elective care, make a plan for "prehabilitation".

Align this with guidance on management of Acute Frailty at www.acutefrailty.org.uk

A version of the CFS is now available on the App Store, designed to help frontline staff calculate a clinical frailty score.

(Dalhousie University, 2021) 
Appendix C

\begin{tabular}{|c|c|}
\hline \multicolumn{2}{|c|}{ SWOT Analysis: Geriatric Frailty Screening } \\
\hline \begin{tabular}{|l} 
Strengths \\
- \\
Highly-skilled interprofessional clinical \\
staff. \\
- $\quad$ Existing interest in frailty identification. \\
- Geriatric-expert APRN project manager.
\end{tabular} & $\begin{array}{ll}\text { Weaknesses } \\
\text { - } & \text { Lack of experiencing using Clinical } \\
& \text { Frailty Scale. } \\
\text { - } & \text { Prolonged EMR build time. } \\
\text { - Interprofessional services too stretched } \\
\quad \text { for additional activity. }\end{array}$ \\
\hline $\begin{array}{l}\text { Opportunities } \\
\text { - } \quad \text { Ability to improve geriatric inpatient } \\
\text { care. } \\
\text { - } \quad \text { Reduce dependence at discharge. } \\
\text { - } \\
\end{array}$ & $\begin{array}{ll}\text { Threats } \\
\text { - } & \text { Competing priorities. } \\
\text { - } & \text { Staff turnover/further short staffing. }\end{array}$ \\
\hline
\end{tabular}




\section{Appendix D}

\section{Project Schedule}

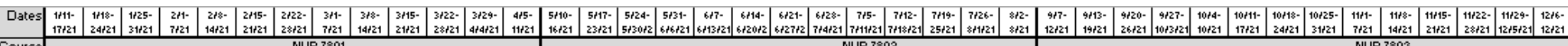

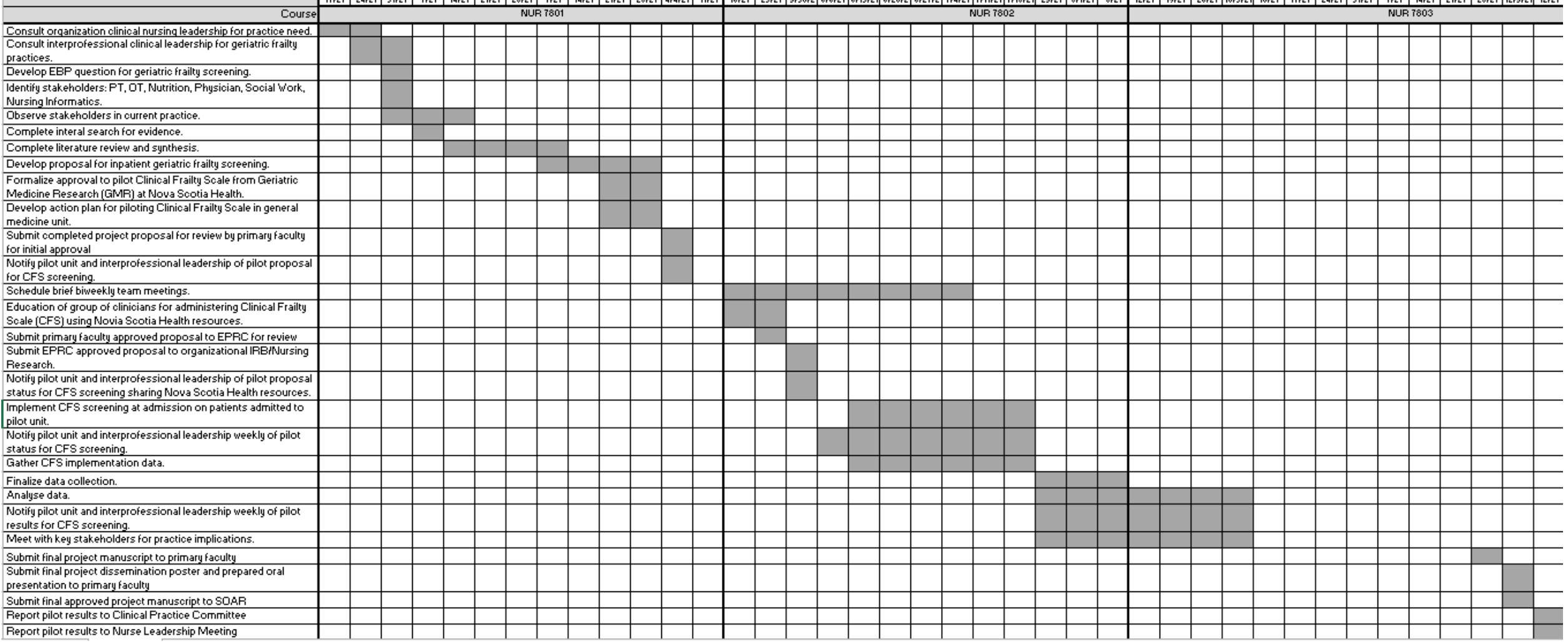

Legend: S, Step of Johns Hopkins Nursing Evidence Based Practice activities. 


\section{Appendix E}

Education tool for project manager to implement Clinical Frailty Scale

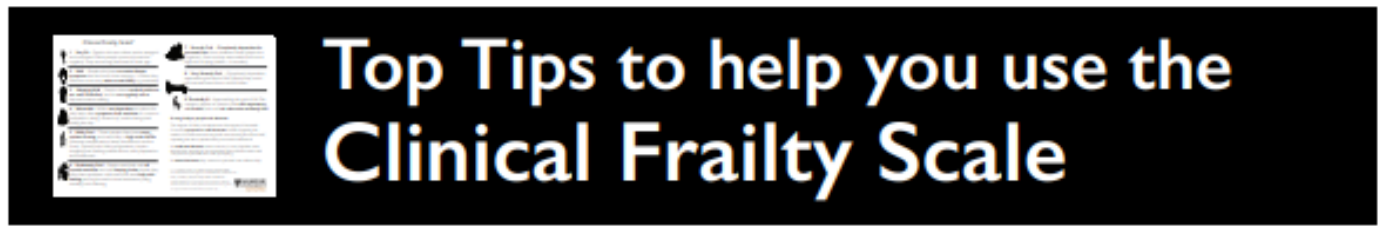

The Clinical Frailty Scale (CFS) was designed to summarise the results of

a Comprehensive Geriatric Assessment. It's now commonly being used as a triage tool to make important clinical decisions, so it is imperative that it is used correctly.

\#1 It's all about the baseline If the person you are assessing is acutely unwell, score how they were 2 weeks ago, not how they are today.

\#2 You must take a proper history The CFS is an objective clinical assessment tool. Frailty must be sensed, described, and measured - not guessed.

\#3 Trust, but verify

What the person you are assessing says is important, but should be cross-referenced with family/carers. The CFS is a judgementbased tool, so you must integrate what you are told, what you observe, and what your professional clinical experience tells you from dealing with older adults

\section{Over-65s only}

The CFS is not validated in people under 65 years of age, or those with stable singlesystem disabilities. However, documenting how the person moves, functions, and has felt about their health may help to create an individualised frailty assessment.

\#5 Terminally ill (CFS 9)

For people who appear very close to death, the current state (i.e. that they are dying) trumps the baseline state.
Having medical problems does not automatically increase the score to CFS 3 A person who isn't bothered by symptoms and whose condition(s) doesn't limit their lives can be CFS I or 2 if theyre active and independent.

\#7 Don't forget “vulnerable” (CFS 4) People in this category are not dependent (though they may need assistance with heavy housework), but often complain of "slowing down". They're becoming sedentary, with poor symptom control.

\#8 Dementia doesn't limit use of the CFS Decline in function in people living with dementia follows a pattern similar to frailty. mild, moderate and severe dementia generally map to CFS 5,6 and 7 respectively. If you don't know the stage of dementia, follow the standard CFS scoring.

Drill down into changes in function

When considering more complex activities of daily living (such as cooking, managing finances, and running the home) the focus is on change in function. A person who has always relied on someone else to perform a particular activity should not be considered dependent for that activity if they've never had to do it before and may not know how. 


\section{Appendix F}

\section{Permission to use Clinical Frailty Scale received 3/31/2021}

DAI.HOUSIF
UNIVERSITY

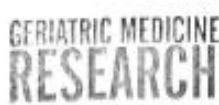

$$
\text { PFH: } 20210331-10
$$

PERMISSION TO USE THE CLINICAL FRAILTY SCALE (CFS)

The undersigned is granted permission to use, reproduce and distribute the Clinical Frailty Scale (CFS), developed by Dr. Kenneth Rockwood, in the format attached! for educational purposes and for non-commercially funded research and/or quality assurance projects The CFS must be adininistered fiee of charge to patients and/or study participants. A formal Licensing Agreement is required for research funded by any commercial entity or pharma and, in some cases, for use in routine clinical care. The copyright holder reserves the vight to prospectively follow-up at any time to determine whether use of the CFS meets the conditions described above. Reselling of the CFS or other commercial development without a license agreement is prohibited by copyripht The undersigned, their delegates and affiliated organization(s) agree that they will not claim ownership rights to the CFS, or any derivative, including translations, compilation, sequel or series. Nothing in this Agreement shall give the undersigned any right, title, or interest in the CFS other than the right to use in accordance with this Agreement. The CFS will not be modified unless explicit permission is granted.

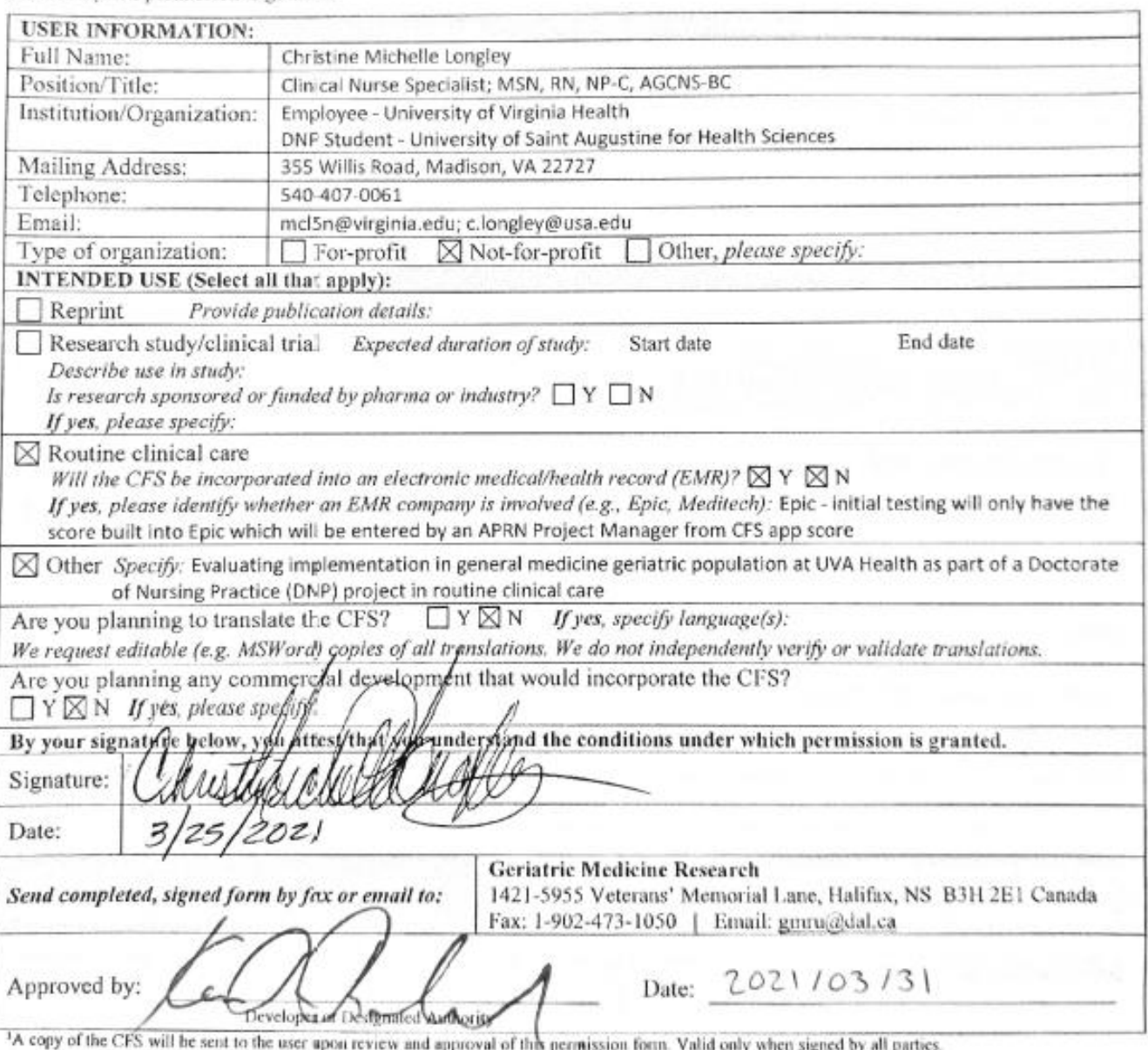

(Dalhousie University, 2021) 


\section{Appendix G}

Procedure for piloting Clinical Frailty Scale

1. Identify geriatric patients who have been admitted in previous 24 hours.

2. Ask primary nurses of newly admitted geriatric patients if there are any safety concerns prior to conversing with patient.

3. Enter patient rooms and perform brief head-to-toe or focused assessment.

4. Explain Clinical Frailty Scale with patient using script "we are asking older patients admitted to this unit a few questions about how much help is needed at home [or institution] two weeks before coming into the hospital. I will go over a few questions with you."

5. Complete Clinical Frailty Scale questions using paper tool.

6. Conclude patient interaction.

7. Discuss results with primary nurse for any interprofessional consult needs.

8. Complete additional components of paper tool.

9. Store paper tool in locked office. 


\section{Appendix H}

\section{Data Collection Tool}

\begin{tabular}{|l|l|l|}
\hline Variable Name & Variable Description & Values \\
\hline Age & Age at start of screening & Years old: \\
\hline Applicable & Was patient appropriate for & $\square \quad 1=$ Yes \\
& screening? & $\square \quad 2=$ No \\
& & $\square \quad 0$ Missing data \\
\hline Completed & Was CFS completed on patient? & $\square \quad 1=$ Yes \\
& & $\square \quad 2=$ No \\
& Clinical Frailty Scale score* & $\square \quad 0=$ Missing data \\
\hline CFS & & $\square \quad 2=$ Very fit \\
& & $\square \quad 3=$ Managing well \\
& & $\square \quad 4=$ Vulnerable \\
& & $\square \quad 5=$ Mildly frail \\
& & $\square \quad 6=$ Moderately frail \\
& & $\square \quad 7=$ Severely frail \\
& & $\square \quad 9=$ Very severely frail \\
& & $\square \quad 0=$ Missing data \\
\hline PlanOfCare & Was a personalized plan of care & $\square \quad 1=$ Yes \\
& created/modified? & $\square \quad 2=$ No \\
& & $\square \quad 0=$ Missing data \\
\hline
\end{tabular}

\section{*Clinical Frailty Scale}

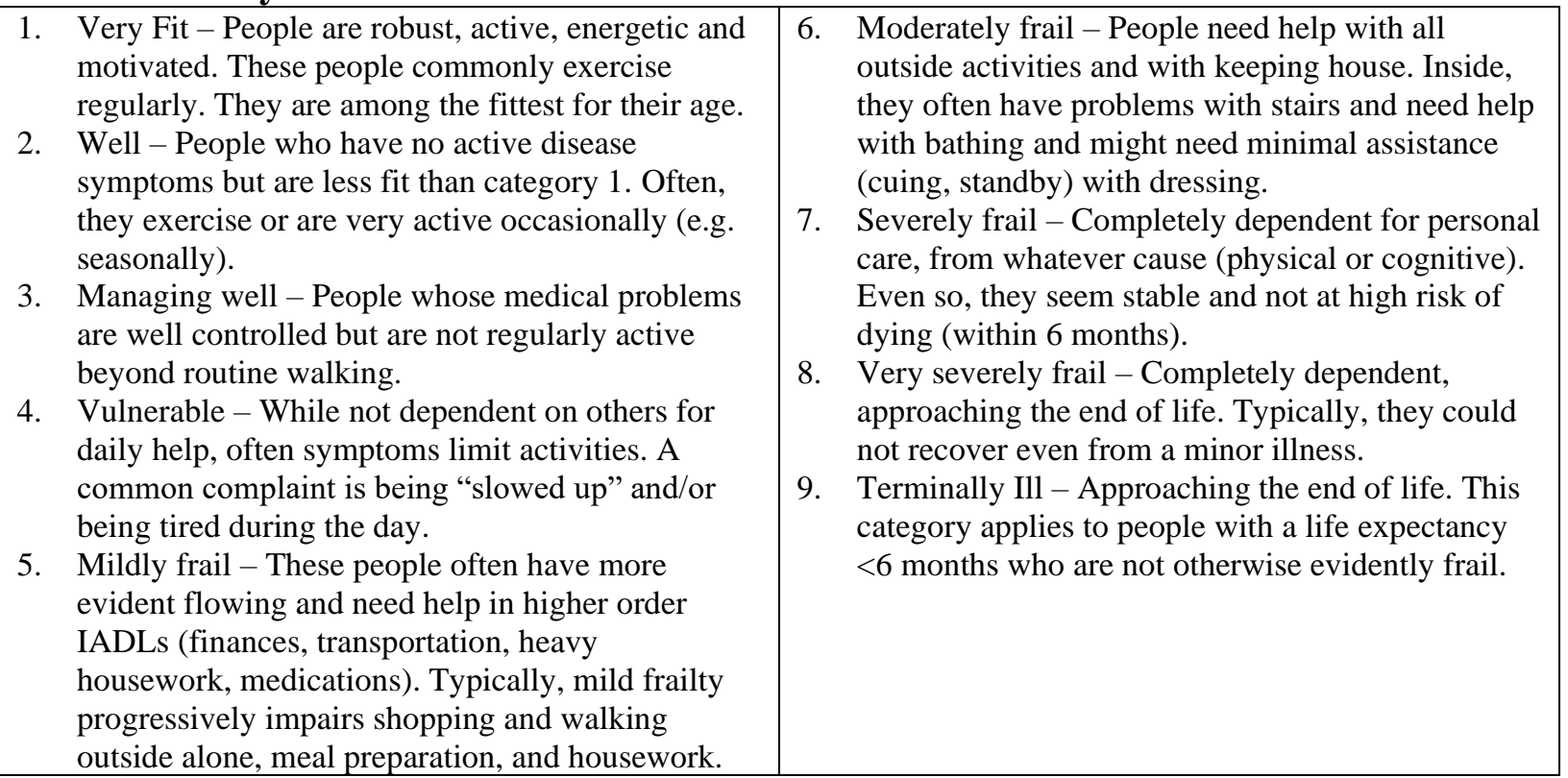

